\title{
Comparison of simulated and observed vegetation for the mid-Holocene in Europe
}

\section{S. Brewer ${ }^{1}$, L. François ${ }^{1}$, R. Cheddadi $^{2}$, J.-M. Laurent ${ }^{1}$, and E. Favre ${ }^{1}$}

${ }^{1}$ Institut d'Astrophysique et de Géophysique, Université de Liège, Bat. B5c, 17 Allée du Six Août, 4000 Liège, Belgium

${ }^{2}$ Université Montpellier II, Institut des Sciences de l'Evolution, case postale 61 CNRS UMR 5554, 34095 Montpellier, France

Received: 21 October 2008 - Accepted: 21 October 2008 - Published: 13 March 2009

Correspondence to: S. Brewer (brewersi@gmail.com)

Published by Copernicus Publications on behalf of the European Geosciences Union.

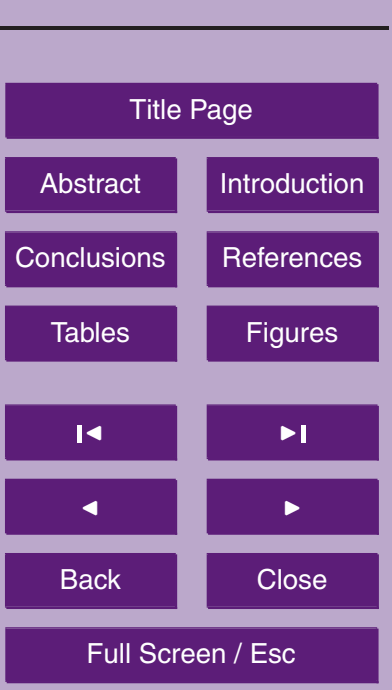

Printer-friendly Version

Interactive Discussion

Mid-Holocene vegetation in Europe

S. Brewer et al. 


\section{Abstract}

Past climates provide a testing bed for the predictive ability of general circulation models. A number of studies have been performed for periods where the climate forcings are relatively different from the present and there is a good coverage of data. For one of these periods, the mid-Holocene (6 ka before present), models and data show a good match over northern Europe, but disagree over the south, where the data show cooler summers and winters and more humid conditions. Understanding the reasons for this disagreement is important given the expected vulnerability of the region under scenarios of future change. We present here a set of different past climate scenarios and sensitivity studies with a global vegetation model in order to try and understand this disagreement. The results show that the vegetation changes can be explained by a combination of both increased precipitation, and a reduction in the length of the growing season, controlled by a reduction in winter temperatures. The matching simulated circulation patterns support the hypothesis of increased westerly flow over this region.

\section{Introduction}

Simulating climates for past periods allow a test of the predictive ability of general circulation models (GCMs) under forcing conditions that are different to those of the present, including changes in orbital parameters, greenhouse gases and land surface conditions. Over the past few years, these tests have been the focus of the Paleoclimate Model Intercomparison Project (PMIP, Braconnot et al., 2007). PMIP has been focused on two key periods, the mid-Holocene $\left(\mathrm{MHL}^{1}\right)$ and the Last Glacial Maximum $\left(\mathrm{LGM}^{2}\right)$. These two periods were chosen as there is a notable change in climate forcings compared to the present: insolation for $\mathrm{MHL}$ and ice sheet and atmospheric $\mathrm{CO}_{2}$ content for the LGM. Further, both periods are relatively data-rich, due to a number of

\footnotetext{
${ }^{1} 6000$ years before present

${ }^{2} 21000$ years before present
}

5, 965-1011, 2009

Mid-Holocene vegetation in Europe

S. Brewer et al.
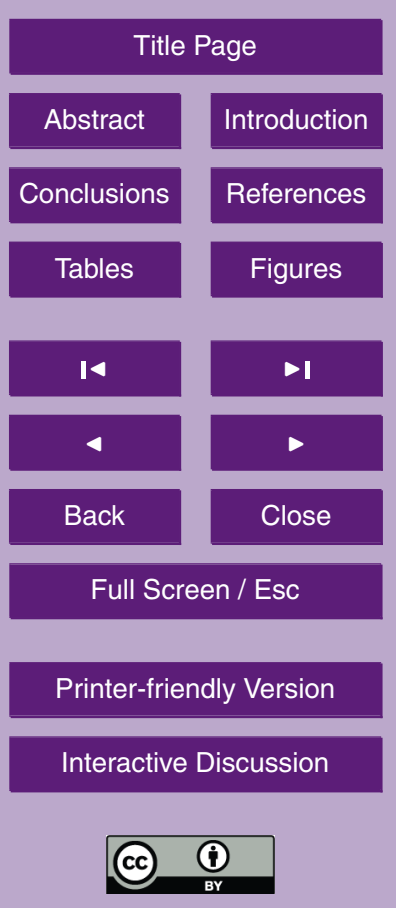
synthesis projects (e.g. Biome6000; Prentice et al., 2000). The data include a range of macro- and micro-organisms that are climate proxies, i.e. have an indirect relation to one or more climate parameters. In terrestrial environments, fossil pollen assemblages make up the most common and widespread climate proxy, and are the data source for 5 most continental comparisons.

In order to compare the output of climate models and fossil pollen assemblages, the two data sources must be converted into compatible parameters. Comparisons are therefore done in one of two ways, either by comparing climate reconstructed from pollen assemblages with that simulated by GCMs (e.g. Bonfils et al., 2004; Brewer 10 et al., 2007), or by finding the potential vegetation that corresponds to the simulated climate space and matching this to the vegetation reconstructed from pollen (Harrison et al., 1998). For the European continent, the majority of these comparison studies have been based on climate parameters (Masson et al., 1999; Bonfils et al., 2004; Brewer et al., 2007), due to the existence of a number of large-scale climate recon15 structions (Cheddadi et al., 1997; Peyron et al., 1998; Davis et al., 2003). Recent developments including the use of fully coupled ocean-atmosphere GCMs (Braconnot et al., 2007), and better accounting for non-climatic conditions in climate reconstructions have led to an improved agreement between models and data, notably for the LGM (Ramstein et al., 2007). However, there remains a mis-match for the MHL period in southern Europe where the cooler and more humid summers reconstructed from the data are rarely simulated by the GCMs (Masson et al., 1999; Brewer et al., 2007). Under scenarios of future change, the Mediterranean is expected to be one of the areas that is most affected. It is therefore important to understand the origins of this datamodel disagreement, in order to assess their ability to predict climate in this region under different forcings.

The mid-Holocene has been used in the PMIP project as most forcing parameters are similar to today, but there is a clear change in radiative forcing, with reduced winter insolation $\left(\sim-6 \mathrm{~W} / \mathrm{m}^{2}\right)$ and increased summer insolation $\left(\sim+6 \mathrm{~W} / \mathrm{m}^{2}\right)$. Climatic reconstructions for Europe show that, instead of a direct response to these changes across
5, 965-1011, 2009

Mid-Holocene vegetation in Europe

S. Brewer et al.
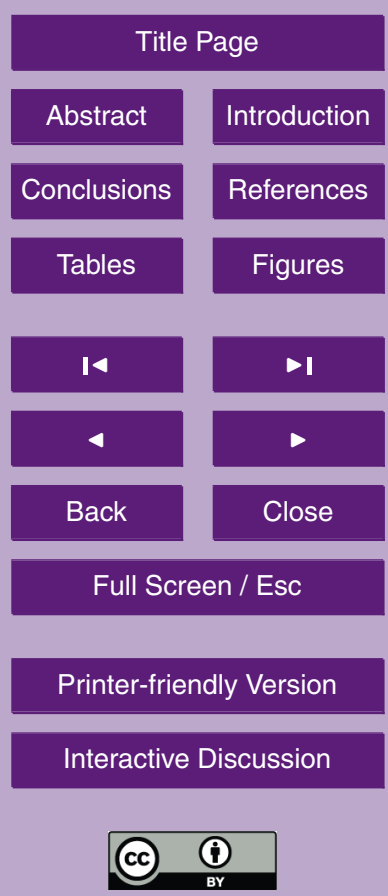
the continent, the climatic response varies on a north-south gradient (Cheddadi et al., 1997; Davis et al., 2003). In the south, winter temperatures are reduced, as a direct response, but in the north, winter warming occurs, due to a strengthening of the high pressure system over the Azores and an advection of warm air masses from the 5 Atlantic Ocean (Masson et al., 1999). A similar pattern is observed in summer temperatures and growing season temperatures (represented as the sum of degree days over $5^{\circ} \mathrm{C}$ : GDD5), with an increase in the north and reduction in the south. Variations in water budget also show a latitudinal trend, with drier conditions in the north of the continent and wetter conditions to the south. This pattern in temperatures is not restricted to 10 the mid-Holocene, but forms part of a long-term opposition in climate changes between the north and south of Europe (Davis et al., 2003; Cheddadi and Bar-Hen, 2008).

Simulations of mid-Holocene climate using atmospheric general circulation models (GCMs) had mixed success in reproducing these observed changes (Masson et al., 1999). In general, the largest mis-match was in the south of Europe were no model 15 was able to simulate the reduction in summer temperatures or GDD5 together with wetter conditions. This has led to criticisms of the reconstructions, suggesting that the vegetation change results from wetter conditions alone. Vegetation depends on the availability of water, rather than the amount of precipitation, and this may be affected by both rainfall and temperature. A sufficient increase in precipitation may therefore be interpreted by a statistical climate reconstruction method as a reduction in temperatures.

At the global scale, the most significant change in vegetation cover for the MHL period is the presence of a green Sahara, facilitated by the intensification of the African Monsoon (Braconnot et al., 2000). In Europe, pollen based biome reconstructions are characterized by a general expansion of temperate forest to both the north and south with respect to the present (REF; Fig. 1). In the north, there is a general expansion of temperate deciduous forest towards the north, replacing what is currently boreal forest and tundra. This follows a general poleward shift in forests seen across high latitudes (Prentice et al., 2000). In the Mediterranean region, there is an expansion of woodland

\section{Mid-Holocene vegetation in Europe}

S. Brewer et al.

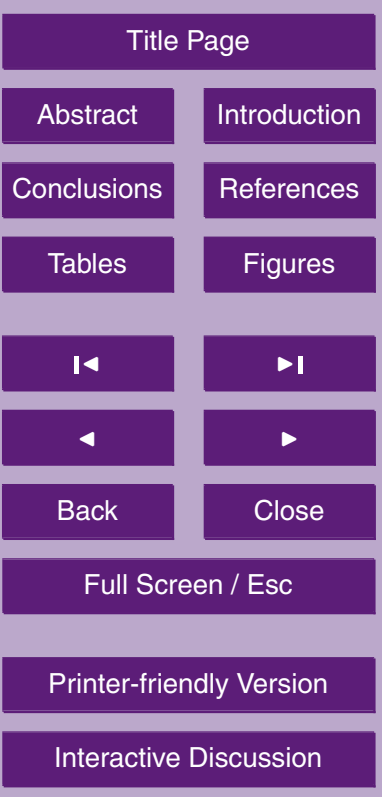

Interactive Discussion

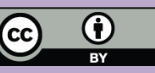


from the early to mid-Holocene (Huntley, 1988, 1990; Davis and Stevenson, 2007), with greater presence of temperate deciduous forest (Fig. 1). There also appears to be a general reduction in the extent of grass and shrubland in this region, although it is unclear from the data whether this is simply due to the reduction in the number of 5 sites at this time. Overall, the distribution of vegetation suggests a reduced north-south difference in climate. The changes in Europe are relatively slight, when compared to the LGM, and this presents a particular challenge for data-model comparison studies.

In the current study we avoid climatic interpretation of the pollen spectra, by comparing the observed vegetation changes during the MHL period to vegetation sim10 ulated using a global vegetation model CARAIB (Otto et al., 2002; François et al., 2006; Laurent et al., 2008) run using palaeo-GCM output. We investigate whether the large-scale changes in vegetation are reproduced in the models (e.g. treeline shifts), then we explore possible reasons for disagreements between data and models, using four different coupled ocean-atmosphere GCMs, which give a range of scenarios of

mid-Holocene climate change and therefore simulate different vegetation changes. By comparing the simulated climate between models with a good agreement, and those with a poor agreement, we attempt to identify the climate parameters that drove the past changes in vegetation. Finally we test the sensitivity of the vegetation response to different climatic parameters, including temperature, precipitation and atmospheric

\section{Methods}

\subsection{Data}

Pollen data was obtained from the Biome 6000 project, version $4.2^{3}$ (Prentice et al., 2000 ) as this currently provides the most complete global set of land cover conditions

\footnotetext{
${ }^{3} \mathrm{http}: / /$ www.bridge.bris.ac.uk/resources/Databases/BIOMES_data
}

5, 965-1011, 2009

\section{Mid-Holocene} vegetation in Europe

S. Brewer et al.

\section{Title Page}

Abstract Introduction

Conclusions References

Tables Figures

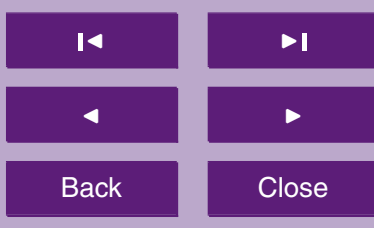

Full Screen / Esc

Printer-friendly Version

Interactive Discussion 
for these two periods. We have used the European sub-region from the global data set (Prentice et al., 1996). The pollen assemblages for these sites have been classified into one of 40 biomes, reclassed into a set of 13 mega-biomes, which are used here (Harrison and Prentice, 2003). These allow the changes in vegetation to be shown in 5 a single synthetic map, and provide a first-order qualitative comparison with the model output. This dataset provided 3620 sites for the modern period (Fig. 1) and 462 sites for the mid-Holocene period (Fig. 1).

More recently, work by Laurent et al. $(2004,2008)$ has provided a finer grain classification, designed for both model and data. This is a set of 26 Bioclimatic Affinity Groups 10 (BAGs, Laurent et al., 2004), defined using the modern climatic space of a set of 320 European plant taxa. For this study, as we simply required a set of biogeographical distributions to provide clear and simple benchmarks for testing the GCM output, we have retained the mega-biomes.

\subsection{Vegetation modelling}

15 The CARAIB vegetation model (Otto et al., 2002; François et al., 2006; Laurent et al., 2008) is a global vegetation model integrating a set of individual modules that provide a detailed simulation of the carbon cycle and biogeography. Canopy photosynthesis and stomatal regulation are calculated using independent $C_{3}$ (Farquhar et al., 1980) and $\mathrm{C}_{4}$ (Collatz et al., 1992) models, every two hours, with a daily update of plant and 20 soil carbon pools. The canopy contains 16 layers, including both tree and shrub/herb layers, which allows for light competition due to the absorption of radiation through the canopy.

Water fluxes are calculated using a soil hydrological model (François et al., 2006). The soil water content is calculated on a daily basis. Input is provided the GCM sim25 ulated precipitation, which is then divided into snow or rainfall according to the daily minimum and maximum temperatures. Snow accumulates in a surface snow reservoir, which can undergo melting and sublimation. Rain water can be intercepted by the foliage (depending on leaf area index, LAI) and either be re-evaporated (depending on

\section{Mid-Holocene vegetation in Europe}

S. Brewer et al.

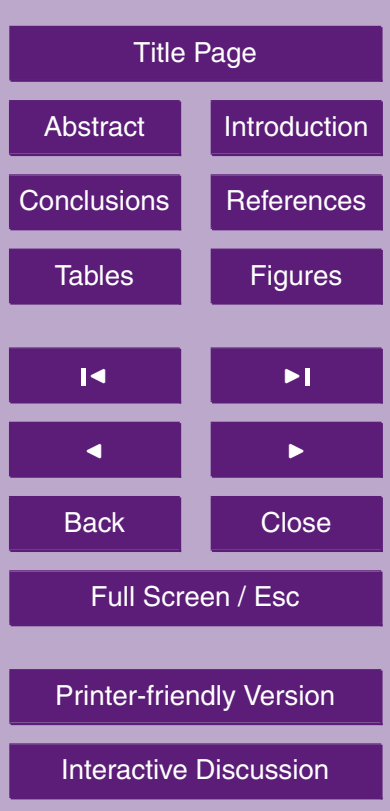

Interactive Discussion 
evaporative conditions) or produce throughfall. Snowmelt and throughfall are the two main input fluxes for soil water. If their sum exceeds maximum infiltration (i.e., soil hydraulic conductivity at saturation), surface runoff is produced. A single reservoir of soil water is used, which corresponds to the root zone, and drainage from this is based 5 on the hydraulic conductivity. Actual evapotranspiration (AET) from the soil/vegetation layer is calculated as a fraction of Penman's potential evapotranspiration (Penman, 1948), depending on soil wetness. Soil water availability can affect stomatal conductance, leaf area index and plant mortality. Transpiration fluxes calculated from stomatal conductance and photosynthetic rates in the carbon cycle module cannot exceed the 10 AET flux calculated by the soil hydrological module. This criterion allows to define a maximum value of the species LAI, on a monthly (herbs/shrubs) or seasonal/annual (trees) basis. Volumetric soil water amounts at wilting point, field capacity and saturation, as well as soil hydraulic conductivity, are functions of soil texture (Saxton et al., 1986).

15 The biogeography module is based on climatic thresholds defined for each group that is simulated. The most important of these control the establishment of plant groups or species and are based on a) the growing season, defined by a minimum number of growing degree days above $5^{\circ} \mathrm{C}$ (GDD5); b) a period of cold temperatures in winter controlling germination; and $c$ ) the existence of a dry period during the year. Plant mortality may also be affected by cold and/or drought events, defined by the coldest day and by soil water availability, as described above. An offline scheme is used to translate the modelled cover and LAI for all plant groups in a given grid cell into a biome class, permitting the model biome distribution to be mapped.

The inputs to CARAIB are a set of climate parameters, including temperature, pre25 cipitation, percentage sunshine, wind speed, relative humidity and diurnal temperature range. These values are required as a set of 12 monthly values for each grid cell. Daily values are produced with a stochastic weather generator (Hubert et al., 1998). In addition, the atmospheric concentration of $\mathrm{CO}_{2}$, orbital parameters and soil texture are required.

\section{Mid-Holocene vegetation in Europe}

S. Brewer et al.

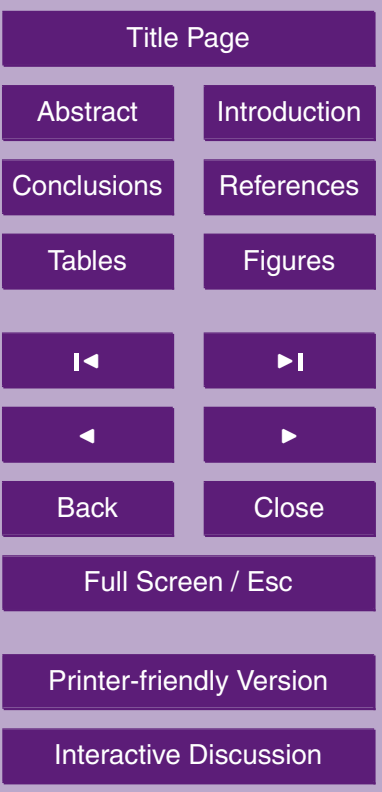

Interactive Discussion

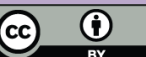


Modern vegetation cover was simulated using conditions as close to pre-industrial as possible. The climatology was calculated from the CRU TS2.0 gridded dataset at a resolution of $0.5 \times 0.5^{\circ}$. Values were estimated as the average of monthly values between 1901 and 1950 (Mitchell and Jones, 2005), to minimise the effect of recent warming.

5 Atmospheric $\mathrm{CO}_{2}$ concentration was set to $279 \mathrm{ppm}$ (Indermühle et al., 1999). The modern distribution of vegetation is shown in Fig. 2.

For the mid-Holocene period, the CARAIB model was driven by output taken from four coupled ocean-atmosphere GCMs from the most recent PMIP comparison experiment, chosen to represent a range of mid-Holocene change scenarios. Details of the 104 GCMs used (ECHAM5-MPIOM1, GISSmodelE, IPSL-CM4-V1-MR, HadCM3M2) are given in Table 1.

In order to obtain input for the vegetation model, monthly anomalies were calculated for each parameter required as the simulated mid-Holocene climate less the control climate. The anomalies were then interpolated to a $0.5^{\circ}$ grid and added to the modern climatology, as described in François et al. (1998, 1999). Atmospheric $\mathrm{CO}_{2}$ concentration was set to 264 ppm (Indermühle et al., 1999).

Sensitivity tests were performed to attempt to isolate the effects of different climate parameters. Four tests were performed (Table 2): a) mid-Holocene climate with modern (pre-industrial) atmospheric $\mathrm{CO}_{2}$ levels (VClim); b) pre-industrial climate with mid-Holocene atmospheric $\mathrm{CO}_{2}$ levels (VCO2); c) pre-industrial temperature and midHolocene precipitation values (VPRC); d) mid-Holocene temperature and pre-industrial precipitation values (VTEM). Other climate inputs were held at the mid-Holocene for experiments VClim, VPRC and VTEM, and at pre-industrial values for VCO2. Only the results obtained from the GISSmodelE sensitivity tests are shown here.

\section{Results}

We have simulated both the biomes distributions and the net primary productivity. All climate models forced CARAIB to simulate a switch from a general dominance of tem-

Mid-Holocene vegetation in Europe

S. Brewer et al.
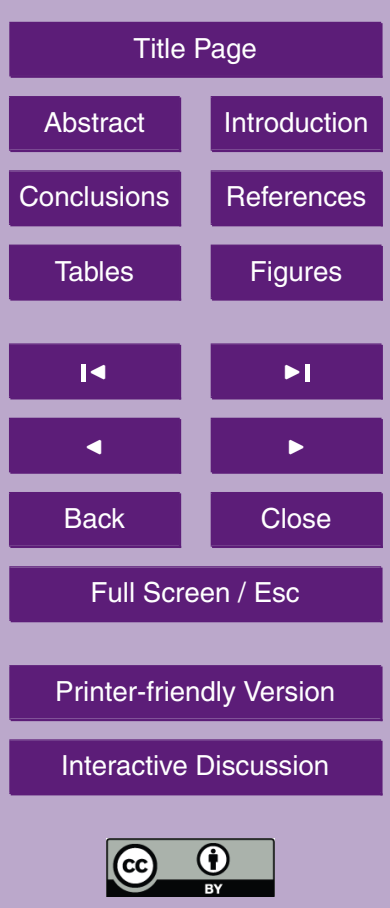
perate deciduous forest in the centre of the continent to cool temperate forest (Fig. 3) and their expansion northward into Scandinavia. This expansion is most notable in Finland and North-west Russia. The distribution of tundra and boreal montane biomes is reduced in all simulations, most clearly usingthe IPSL-CM4-V1-MR climatology (Figs. 3 5 and 4). To help interpret this vegetation dynamics we have investigated the changes in soil water availability and the length and intensity of the growing season for the four GCMs.

- The ECHAM5-MPIOM1 simulation (Fig. 3a) shows a very similar distribution of biomes to the pre-industrial simulation, with some small increases in the distribution of grassland and semi-desertic biomes in Northern Africa.

- The GISSmodelE simulation (Fig. 3b) shows different changes in the west and east of the Mediterranean basin, with a southward expansion of warm/temperate open forest, most notably in Northern Africa where it replaces grassland and semidesert, and an increase of warm/temperate mixed forest in the Iberian peninsula, indicating a closing of the forest. In the south-east, warm/temperate open forest expand northward in the Balkan peninsula.

- The IPSL-CM4-V1-MR simulation (Fig. 3c) shows a more widespread opening of the forest in the southeast, reaching up into the Pannonian basin, but little change from the present in the south-west.

- The expansion of the warm/temperate open forest using simulations from the HadCM3M2 (Fig. 3d) and the GISSmodelE (Fig. 3b) is similar. In both cases we observe an expansion southward in the west and northward in the east.

The soil water availability changes (Fig. 5) are similar from all four GCM input, with an overall decrease in northern Scandinavia, due to the warmer and dryer conditions and an increase in the Iberian peninsula. The output from ECHAM5-MPIOM also shows a slight increase in eastern Europe, north of the Carpathian mountain chain, and the

Mid-Holocene vegetation in Europe

S. Brewer et al.
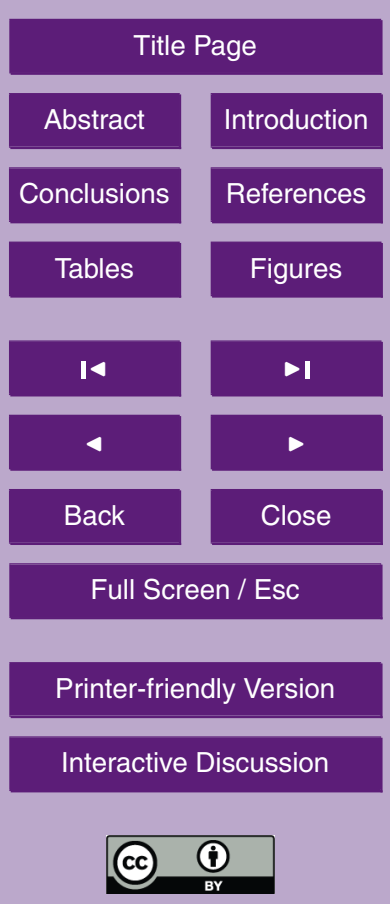
HadCM3M2 simulations shows some drying in North-West Europe (France and the UK).

The GDD5 (Fig. 6) shows a general increase across Europe for all simulations. This tends to form a gradient from high values in the north-east to lower values and some 5 reduction in GDD5 values in the south-west. The exception to this is GISSmodelE, which shows a marked lowering across the south of the study area. The simulated biomes distributions for the mid-Holocene (Fig. 3) show a greater variation between model output in the south of the continent.

The simulated net primary productivity (NPP) shows a general decline (Fig. 7) during 10 the mid-Holocene when compared to the pre-industrial period (Table 3). There is also some regional variation between the north-west, north-east, south-west and south-east of Europe (Fig. 5). While all regions show a range of positive and negative values, the results show the largest reductions in the northern regions, with in general (over $75 \%$ of pixels) a decline. The reduction is less marked in the south, shown by a median close 15 to zero. The simulations are again more varied in the south-west, with HadCM3M2 simulations showing a balance of increases and decreases, and an overall trend to increased NPP in the GISSmodelE simulation.

\section{Discussion}

In this discussion of the results, we first compare the simulated vegetation distributions 20 against observations, in order to identify the GCM output that provides the best agreement. The robustness of the simulations is also tested by comparison with two previous simulations of European MHL vegetation. We then try and isolate the climate factors driving this vegetation shift by examining a) changes in the simulated GCM monthly climatologies; and $b$ ) the effect of changing different parameters on the MHL vegetation

distribution, which also allows us to account for the role played by the slight change in atmospheric $\mathrm{CO}_{2}$ concentration. Finally, we use the information obtained to test a hypothesis of mid-Holocene circulation change over the study area.

\section{Mid-Holocene vegetation in Europe}

S. Brewer et al.

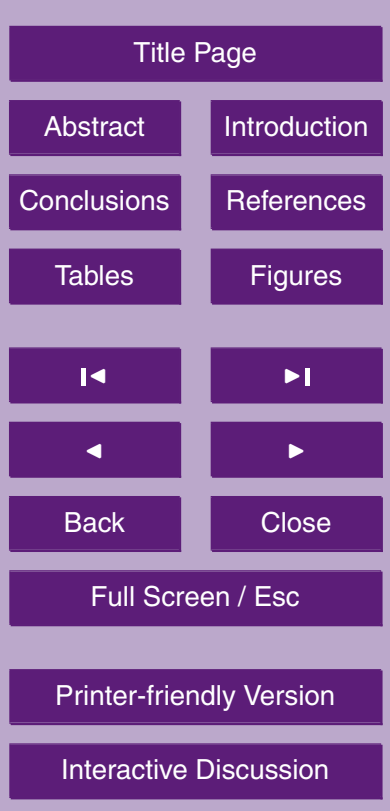

Interactive Discussion 
The simulated changes in the vegetation cover of Europe obtained in this study show little difference to the modern day potential cover, and the results obtained from the output of the different GCMs are very similar. This is unsurprising given the relatively small climatic changes between the mid-Holocene and the pre-industrial climatology 5 used here. The most notable and consistent change is in the composition of the forest cover of the centre of Europe, with a change to a slightly cooler forest type. Pollen spectra from this time show a transition from an early Holocene forest dominated by Pinus, Betula, Corylus and Quercus to one composed of Fagus, Picea, Carpinus and Quercus (Huntley, 1990). The simulated biome distribution therefore offers a view of 10 the potential vegetation cover prior to the acceleration of human impact in the second half of the Holocene (Roberts, 1998; Marchant et al., 2009). The relatively small change also suggests that, within the climatic changes between the mid-Holocene and the pre-industrial, the vegetation distribution of Europe is fairly stable in its structure, if not in its composition.

15 In the north of Europe, the observed poleward spread of temperate forests is observed in all the simulations, although there is less expansion in Sweden and Norway than in the data. Pollen sequences suggest that this expansion covered between 50 and $100 \mathrm{~km}$ (Kaplan et al., 2003), and this agrees with the expansion in Finland and northwest Russia. In contrast, while an overall reduction of tundra is observed in all models (Fig. 4), there is no clear geographical representation of this (Fig. 3). This is at least in part due to the different methods of classifying tundra in the data and the models. Tundra biome is simulated in CARAIB when GDD5 values and/or LAI values drop below a certain threshold, whereas the pollen tundra biomes are based on representivity of a set of plant functional types (Prentice et al., 1996). Boundaries between simulated tundra and other biomes tend to be more sharply defined, causing a difference in geographical distribution. This is particularly noticeable for the modern pollen biome distribution, where tundra is recreated in a few pollen samples in southern Europe. This is due to a high presence of species found in anthropogenic heathlands, which have a similar composition of pollen taxa, while differing in the plant specific
$5,965-1011,2009$

Mid-Holocene vegetation in Europe

S. Brewer et al.

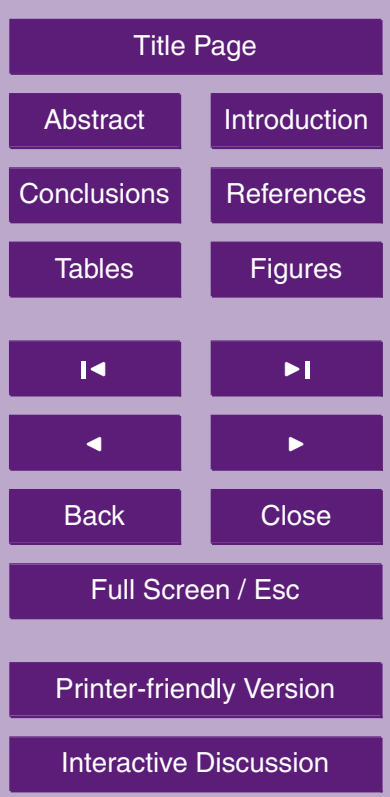

Interactive Discussion

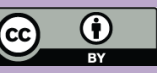


composition (Prentice et al., 1996).

The observed changes in the south of Europe are more complex, and varied between the four GCMs. Simulated biome distributions from two of these (ECHAM-MPIOM1 and IPSL-CM4-V1-MR) show no distinct change from the modern distribution. In contrast, 5 the remaining two GCMs do show a development of an open forest type, particularly in the southwest, at the expense of the grassland cover, which matches the description of an expansion of forest in the Mediterranean (Huntley, 1990; Davis and Stevenson, 2007). The observed southward expansion of deciduous temperate forest (Fig. 1) is not seen in the simulations. This supports previous studies indicating that although 10 the direction of the simulated mid-Holocene climate change may be correct, the amplitude is not (Brewer et al., 2007). However, it should be noted that there are few data points in the centre of the Iberian peninsula (Fig. 1). A recent study of sites situated in the Ebro desert suggest that the increased precipitation during this period was not large enough to support large populations of temperate deciduous trees (Davis and 15 Stevenson, 2007), indicating a landscape closer to that obtained from GISSmodelE and HadCM3M2.

The disagreements between observed and simulated MHL vegetation described above are similar to that found in previous studies. Prentice et al. (1998) simulated biome distribution for the mid-Holocene, using the BIOME model with output from 20 NCAR CCM1 GCM, coupled to a mixed layer ocean model. As with the present results, they found an insufficient northward extension of deciduous forests and little of no southward extension. They also note a simulated expansion of steppe-like vegetation to the north of the Black Sea, as found here in the IPSL and HadCM3M2 simulations. Kaplan et al. (2003) compared simulated and observed vegetation north of $55^{\circ} \mathrm{N}$ us25 ing the BIOME4 model and two coupled ocean-atmosphere GCMs. Their results also showed that while deciduous forests expanded in Fennoscandia, this is less than that observed in the data, due to insufficient winter warming.

Based on the comparison of the different vegetation simulations, the GISSmodelE run simulates changes that are the closest to the observations, notably in the south-

\section{Mid-Holocene vegetation in Europe}

S. Brewer et al.

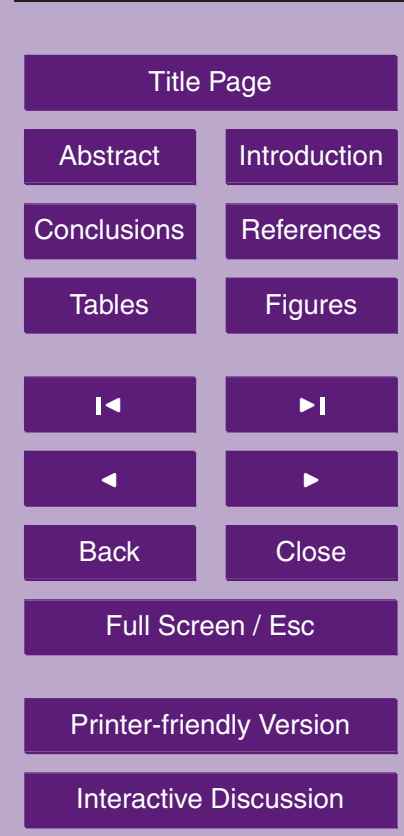

Interactive Discussion

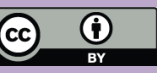


west. In order to identify the climatic changes that drove these changes, we compare the anomaly climatologies for each GCM (Fig. 9). The temperature anomalies show a clear shift to a more seasonal climate, and that the influence of the insolation changes (Berger, 1978) dominates this climatic parameter.

5 The climatologies show little evidence for winter warming in the north, with most temperature changes close to zero. The exceptions are the ECHAM5-MPIOM1 model (Fig. 8) in the northwest and the IPSL-CM4-V1-MR model in the NE (Fig. 8). Warmer winters are necessary for the observed expansion in deciduous and mixed forests in Fennoscandia (Prentice et al., 1998) and this explains the limited response in the sim10 ulations. As these are regional averages, there may have been some greater but localised warming, and the pattern of treeline shifts suggests that there was a land-sea gradient, with greater warming toward the continental interior. This is consistent with reconstructed warmer winter temperatures in the east of Europe (Davis et al., 2003). Precipitation changes in the north show no obvious pattern with a mixture of positive 15 and negative anomalies. One exception to this is the ECHAM5-MPIOM1 simulation, which shows a general increase in precipitation throughout the year.

In the south, changes in precipitation appear to play the most important role. An increase in summer precipitation is seen in both models (GISSmodelE, HadCM3M2) that show the same type of vegetation change as in the data, i.e. towards greater for20 est cover in the south-west (Figs. 8b and d). The GISSmodelE also shows a general cooling throughout the year, with a much smaller summer increase than the other models, suggesting that temperature change may also have helped drive the vegetation changes. In the south-east, an increase in precipitation is simulated by the ECHAM5MPIOM1 model throughout the majority of the year, and this is the only model to not show an expansion of steppe vegetation in this region.

In terms of parameters that control the distribution of plants more directly, these changes translate into an increase in soil water availability (Fig. 5) and a decrease in GDD5 (Fig. 6). However, while all models show an increase in soil water in the Iberian peninsula, that covers a greater or lesser spatial area, an expansion of forest types

5, 965-1011, 2009

Mid-Holocene vegetation in Europe

S. Brewer et al.

Title Page

Abstract Introduction

Conclusions References

Tables Figures

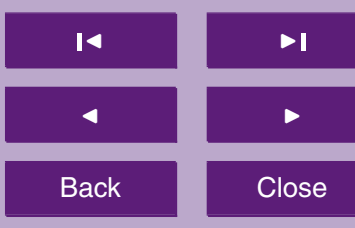

Full Screen / Esc

Printer-friendly Version

Interactive Discussion

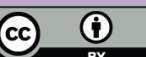


is not seen in all simulations. This supports the role of temperature changes in the mid-Holocene vegetation, in particular a marked lowering of GDD5. This change is of interest, as it shows that this variable is controlled by winter temperature changes in the south of Europe, and a reduction may occur, even when the summer temperature 5 increases.

The results show a general decline in NPP for the mid-Holocene across Europe (Table 3), with regional variations (Fig. 7). This fits with the slight decline in mid-Holocene global NPP described by Beerling and Woodward (2001), using two GCMs, although the variations given by these authors for the European latitudes are very close to mod10 ern values. However, the results obtained by Peng et al. (1998), using a statistical modelling approach based on pollen data, show an increase in NPP for this period. This second study does not explicitly model the photosynthetic process, and does not take into account the small change in atmospheric $\mathrm{CO}_{2}$ concentration at the mid-Holocene.

From the sensitivity experiments (Fig. 9), it is possible to attribute the decline in 15 NPP in the east of Europe to both changes in climate (VClim) and $\mathrm{CO}_{2}$ (VCO2) concentration. Equally, while winter temperature played an important role in changing the composition of the forests in the north-east (Prentice et al., 2000), and water availability in the south-east (Prentice et al., 2000), experiments with modern temperature (VPRC) or modern precipitation (VTEM) indicate that productivity in these regions was affected by changes in both these variables.

In the north-west, changing $\mathrm{CO}_{2}$ concentration alone results in a decrease of NPP equal to approximately $50 \%$ of the combined climate and $\mathrm{CO}_{2}$ effect. In contrast, when $\mathrm{CO}_{2}$ is kept at modern levels and climate changed, this reduction is much smaller. This may be due to a strong gradient of climate anomalies in this region. Holding precipitation or temperature to modern values causes a similar reduction, although the mid-Holocene temperatures cause a larger change when compared to modern values. Productivity increases in the south-west during the mid-Holocene. The sensitivity experiments suggest that this increase comes from the climate change, offset by a reduction due to lower $\mathrm{CO}_{2}$ concentration. Changing precipitation appears to account for
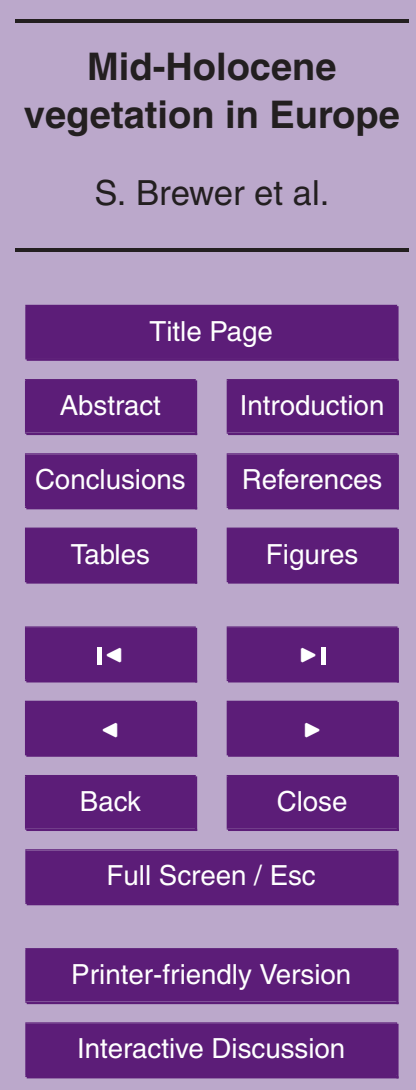

Interactive Discussion 
all of the climatically induced NPP changes, whereas temperature has little effect.

In general, the change due to $\mathrm{CO}_{2}$ concentration variation is relatively high, matching the effect of climate change in east of Europe. However, these changes are small, and further work will be necessary to test the sensitivity of CARAIB to $\mathrm{CO}_{2}$.

5 Bonfils et al. (2004) proposed a scenario of circulation changes to explain the observed mid-Holocene winter climate in Europe. We examine here whether the GCM providing the best fit to the data in this study (GISSmodelE) supports this. The scenario is based on the existence of an anomalous low pressure system located over north-west Europe causing an increased westerly flow over the south-west and bring10 ing moisture into the Mediterranean basin. Any heating from the advection of these air masses was offset by the reduction in insolation (Bonfils, 2001; Bonfils et al., 2004). Having lost moisture, the air masses then flowed north were the smaller insolation anomalies were no longer sufficient to prevent warming.

Changes in surface wind from the GISSmodelE simulation, which provided the best 15 fit to the data, support this scenario (Fig. 10), with a clear counter-clockwise and increased westerly flow over the Mediterranean. This is, however, slightly displaced to the north and west compared to Bonfils et al. (2004), and this may have limited the advection of moisture towards the interior, resulting in the reduced moisture availability in south eastern Europe. A similar pattern can be seen in both the HadCM3M2 20 and ECHAM5-MPIOM GCMs, but in both cases, the area of low pressure is positioned further to the north-west. This limits the westerly flow in the HadCM3M2 model and results in a more southerly flow in the ECHAM5-MPIOM. This pattern appears to be absent in the IPSL-CM4-V1-MR wind patterns (Fig. 10).

\section{Conclusions}

- Simulated vegetation distributions based on coupled ocean-atmosphere GCMs show a poleward shift in Fennoscandia, with a corresponding loss of tundra and boreal montane forest, that are consistent with the observed changes.

\section{Mid-Holocene vegetation in Europe}

S. Brewer et al.

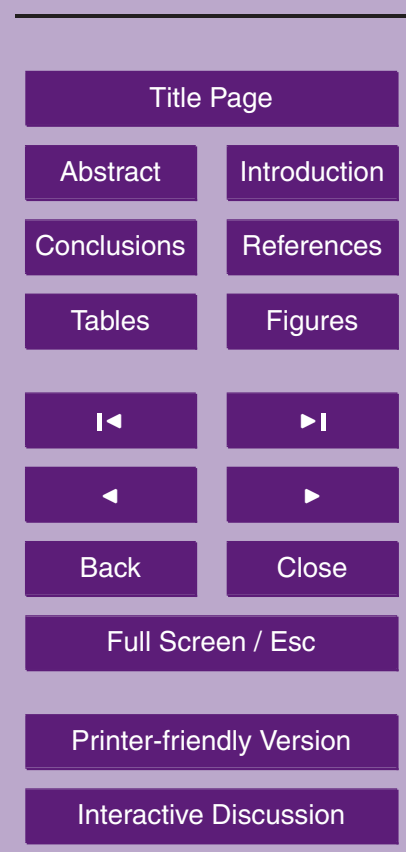


- In central Europe there is a change in forest composition in central European forests toward a dominance of cool temperate forest types.

- The observed southward spread of temperate forests is not observed in any model, but two simulations show an increase in forest cover, with loss of desert, semi-desert and temperate grasslands.

- Changes in the south are driven by increased moisture availability, but lower winter temperatures also played a role. In the Mediterranean region, a decrease in the relatively higher winter temperatures leads to a decrease in GDD5, which may be reconstructed as lower summer temperatures.

- The observed pattern of changes is consistent with increased westerly flow from Atlantic, bringing increased precipitation over the Mediterranean basin.

Acknowledgements. Financial support for the study was provided by FRFC convention no. 2.4555.06. The work forms part of project DECVEG from the European Science Foundation (ESF) under the EUROCORES Programme EuroCLIMATE, through contract No. ERASCT-2003-980409 of the European Commission, DG Research, FP6. We thank the PMIP2 Database (http://pmip2.Isce.ipsl.fr/) for providing GCM data.
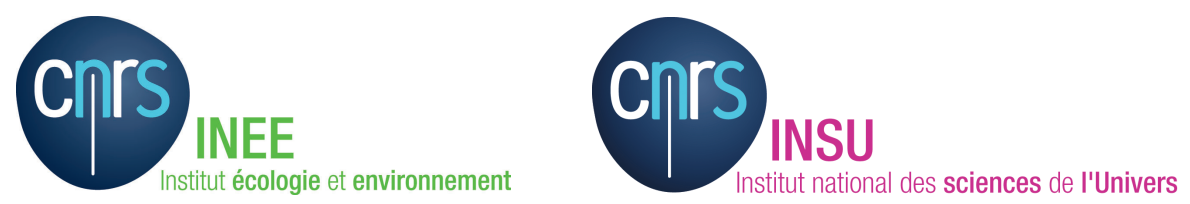

Publication of this paper was granted by EDD (Environnement, Développement Durable) and INSU (Institut des Sciences de l'Univers) at CNRS.

\section{References}

Beerling, D. and Woodward, F.: Vegetation and the Terrestrial Carbon Cycle: Modelling the First 400 Million Years, Cambridge University Press, 2001. 978

Mid-Holocene vegetation in Europe

S. Brewer et al.

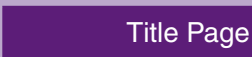

Abstract Introduction

Conclusions References

Tables Figures

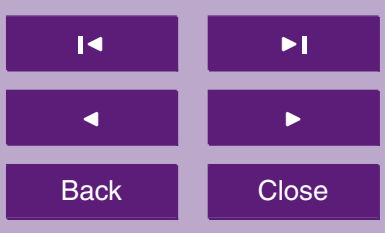

Full Screen / Esc

Printer-friendly Version

Interactive Discussion 
Berger, A.: Long-term variations of daily insolation and Quaternary climatic changes, J. Atmos. Sci., 35, 2362-2367, 1978. 977

Bonfils, C.: Le moyen-Holocène: rôle de la surface continentale sur la sensibilité climatique simulée, Ph.D. thesis, Université Paris VI, Paris, 322 pp., 2001. 979

5 Bonfils, C., de Noblet-Ducoudré, N., Guiot, J., and Bartlein, P. J.: Some mechanisms of midHolocene climate change in Europe, inferred from comparing PMIP models to data, Clim. Dynam., 23, 79-98, 2004. 967, 979

Braconnot, P., Joussaume, S., de Noblet, N., and Ramstein, G.: Mid-Holocene and last glacial maximum African monsoon changes as simulated within the Paleoclimate Modeling Inter10 comparison project, Global Planet. Change, 26, 51-66, 2000. 968

Braconnot, P., Otto-Bliesner, B., Harrison, S., Joussaume, S., Peterchmitt, J.-Y., Abe-Ouchi, A., Crucifix, M., Driesschaert, E., Fichefet, Th., Hewitt, C. D., Kageyama, M., Kitoh, A., Laîné, A., Loutre, M.-F., Marti, O., Merkel, U., Ramstein, G., Valdes, P., Weber, S. L., Yu, Y., and Zhao, Y.: Results of PMIP2 coupled simulations of the Mid-Holocene and Last Glacial Maximum Part 1: experiments and large-scale features, Clim. Past, 3, 261-277, 2007, http://www.clim-past.net/3/261/2007/. 966, 967

Brewer, S., Guiot, J., and Torre, F.: Mid-Holocene climate change in Europe: a data-model comparison, Clim. Past, 3, 499-512, 2007, http://www.clim-past.net/3/499/2007/. 967, 976

Cheddadi, R. and Bar-Hen, A.: Spatial gradient of temperature and potential vegetation feedback across Europe during the late Quaternary, Clim. Dynam., 32(2-3), 371-379, 2008. 968

Cheddadi, R., Yu, G., Guiot, J., Harrison, S. P., and Prentice, I. C.: The climate of Europe 6000 years ago, Clim. Dynam., 13, 1-9, 1997. 967, 968

Collatz, G., Ribas-Carbo, M., and Berry, J.: Coupled photosynthesis-stomatal conductance model for leaves of $\mathrm{C}_{4}$ plants, Aust. J. Plant Physiol., 19, 519-538, 1992. 970

Davis, B. A. S. and Stevenson, A. C.: The 8.2 ka event and early mid-Holocene forests, fires and flooding in the Central Ebro Desert, NE Spain, Quaternary Sci. Rev., 26, 1695-1712, 2007. 969,976

30 Davis, B. A. S., Brewer, S., Stevenson, A. C., Guiot, J., and Data contributors: The temperature of Europe during the Holocene reconstructed from pollen data, Quaternary Sci. Rev., 22, 1701-1716, 2003. 967, 968, 977

Farquhar, G., von Caellerer, S., and Berry, J.: A biogeochemical model of photosynthetic $\mathrm{CO}_{2}$

\section{Mid-Holocene vegetation in Europe}

S. Brewer et al.

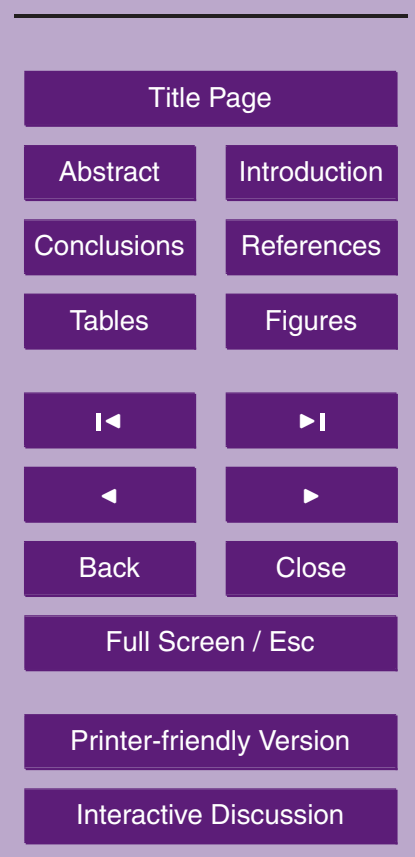


assimilation in leaves of $C_{3}$ species, Planta, 149, 78-90, 1980. 970

François, L., Delire, C., Warnant, P., and Munhoven, G.: Modelling the glacial-interglacial changes in the continental biosphere, Global Planet. Change, 16-17, 37-52, 1998. 972

François, L., Goddéris, Y., Warnant, P., Ramstein, G., de Noblet, N., and Lorenz, S.: Carbon stocks and isotopic budgets of the terrestrial biosphere at mid-Holocene and last glacial maximum times, Chem. Geol., 159, 163-189, 1999. 972

François, L., Ghislain, M., Otto, D., and Micheels, A.: Late Miocene vegetation reconstruction with the CARAIB model, Palaeogeography, Palaeoclimatology, Palaeoecology, 238, 302320, 2006. 969, 970

10 Harrison, S. P. and Prentice, I. C.: Climate and $\mathrm{CO}_{2}$ controls on global vegetation distribution at the last glacial maximum: analysis based on palaeovegetation data, biome modelling and palaeoclimate simulations, Global Change Biol., 9, 983-1004. 970

Harrison, S., Jolly, D., Laarif, F., Abe-Ouchi, A., Dong, B., Herterich, K., Hewitt, C. D., Joussaume, S., Kutzbach, J., Mitchell, J., De Noblet, N., and Valdes, P.: Intercomparison of simulated global vegetation distributions in response to $6 \mathrm{kyr}$ BP orbital forcing, J. Climate, 11, 2721-2742, 1998. 967

Hubert, B., François, L., Warnant, P., and Strivay, D.: Stochastic generation of meteorological variables and effects on global models of water and carbon cycles in vegetation and soils, $\mathrm{J}$. Hydrol., 212-213, 318-334, 1998. 971

20 Huntley, B.: Europe, in: Vegetation History, edited by: Huntley, B. and Webb III, T., 341-383, Kluwer Academic Publishers, New York, 1988. 969

Huntley, B.: European post-glacial forests: compositional chnages in response to climatic change, J. Veg. Sci., 1, 507-518, 1990. 969, 975, 976

Indermühle, A., Stocker, T. F., Joos, F., Fischer, H., Smith, H. J., Wahlen, M., Deck, B., Mastroianni, D., Tschumi, J., Blunier, T., Meyer, R., and Stauffer, B.: Holocene carbon-cycle dynamics based on $\mathrm{CO}_{2}$ trapped in ice at Taylor Dome, Antarctica, Nature, 398, 121-126, doi:10.1038/18158, 1999. 972

Kaplan, J. O., Bigelow, N. H., Prentice, I. C., Harrison, S. P., Bartlein, P. J., Christensen, T. R., Cramer, W., Matveyeva, N. V., McGuire, A. D., Murray, D. F., Razzhivin, V. Y., Smith, B., so Walker, D. A., Anderson, P. M., Andreev, A. A., Brubaker, L. B., Edwards, M. E., and Lozhkin, A. V.: Climate change and arctic ecosystems II: Modeling, paleodata-model comparisons, and future projections, J. Geophys. Res., 108, 8171, doi:10.1029/2002JD002559, 2003. 975, 976

\section{Mid-Holocene vegetation in Europe}

S. Brewer et al.

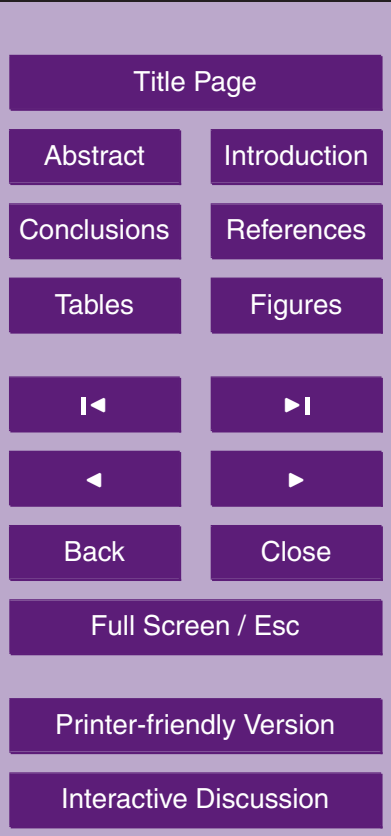

Interactive Discussion 
Laurent, J.-M., Bar-Hen, A., François, L., Ghislain, M., and Cheddadi, R.: Refining vegetation simulation models: From plant functional types to bioclimatic affinity groups of plants, J. Veg. Sci., 15, 739-746, 2004. 970

Laurent, J.-M., François, L., Bar-Hen, A., Bel, L., and Cheddadi, R.: European Bioclimatic $5 \quad$ Affinity Groups: data-model comparisons, Global Planet. Change, 61, 28-40, doi:10.1016/j. gloplacha.2007.08.017, 2008. 969, 970

Marchant, R., Brewer, S., Webb III, T., and Turvey, S.: Holocene deforestation: a history of human-environmental interactions, climate change and extinction, in: Holocene Extinctions, edited by: Turvey, S., Oxford University Press, in press, 2009. 975

10 Masson, V., Cheddadi, R., Braconnot, P., Joussaume, S., Texier, D., and PMIP Participants: Mid-Holocene climate in Europe: what can we infer from PMIP model-data comparisons?, Clim. Dynam., 15, 163-182, 1999. 967, 968

Mitchell, T. and Jones, P.: An improved method of constructing a database of monthly climate observations and associated high-resolution grids, Int. J. Climatol., 25, 693-712, 2005. 972

Otto, D., Rasse, D., Kaplan, J., Warnant, P., and François, L.: Biospheric carbon stocks reconstructed at the Last Glacial Maximum: comparison between general circulation models using prescribed and computed sea surface temperatures, Global Planet. Change, 33, 117-138, 2002. 969, 970

Penman, $\mathrm{H}$.: Natural evaporation from open water, bare soil and grass, Proc. Roy. Soc. Ser. A, 193, 120-145, 1948. 971

Peyron, O., Guiot, J., Cheddadi, R., Tarasov, P., Reille, M., De Beaulieu, J. L., Bottema, S., and Andrieu, V.: Climatic Reconstruction in Europe for 18,000 Yr B.p. From Pollen Data, Quaternary Res., 49, 183-196, 1998. 967

Prentice, I., Jolly, D., and Biome 6000 Participants: Mid-Holocene and glacial-maximum vegetation geography of the northern continents and Africa, J. Biogeogr., 27, 507-519, doi: 10.1046/j.1365-2699.2000.00425.x, 2000. 967, 968, 969, 978

Prentice, I. C., Guiot, J., Huntley, B., Jolly, D., and Cheddadi, R.: Reconstructing biomes from palaeoecological data: a general method and its application to European pollen data at 0 and $6 \mathrm{ka}$, Clim. Dynam., 12, 184-194, 1996. 970, 975, 976

30 Prentice, I. C., Harrison, S., Jolly, D., and Guiot, J.: The climate and biomes of Europe at 6000 yr BP: comparison of model simulations and pollen-based reconstructions, Quaternary Sci. Rev., 17, 659-668, 1998. 976, 977

Ramstein, G., Kageyama, M., Guiot, J., Wu, H., Hély, C., Krinner, G., and Brewer, S.: How cold

\section{Mid-Holocene vegetation in Europe}

S. Brewer et al.

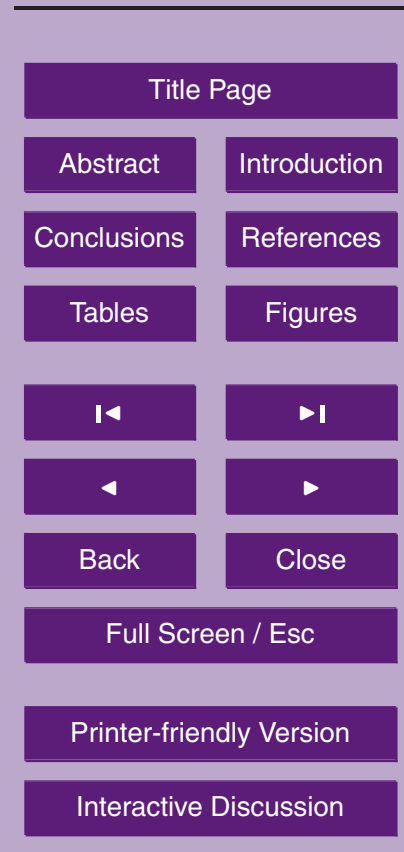

Interactive Discussion 
was Europe at the Last Glacial Maximum? A synthesis of the progress achieved since the first PMIP model-data comparison, Clim. Past, 3, 331-339, 2007,

http://www.clim-past.net/3/331/2007/. 967

Roberts, N.: The Holocene: an environmental history, Blackwell, 1998. 975

5 Saxton, K., Rawls, W., Romberger, J., and Papendick, R.: Estimating generalized soil-water characteristics from texture, Soil Sci. Soc. Am. J., 50, 1031-1036, 1986. 971
5, 965-1011, 2009

Mid-Holocene vegetation in Europe

S. Brewer et al.

\section{Title Page}

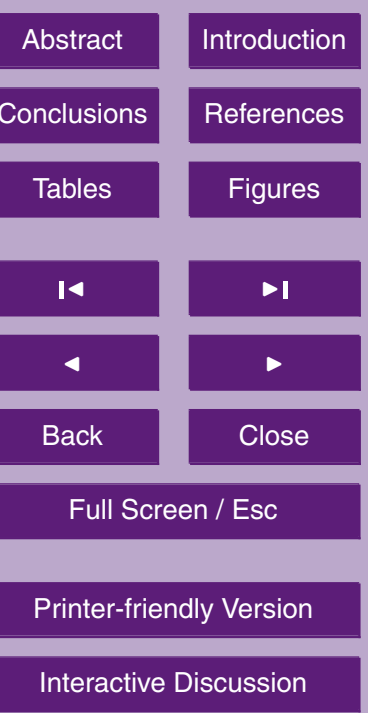


$5,965-1011,2009$

Mid-Holocene vegetation in Europe

S. Brewer et al.

Table 1. PMIP2 coupled ocean-atmosphere GCMs used in this study.

\begin{tabular}{lll}
\hline Model & Resolution & Reference \\
\hline ECHAM5-MPIOM1 & T63 & Jungclaus et al. (2005) \\
GISSmodelE & $5 \times 4^{\circ}$ & Schmidt et al. (2006) \\
IPSL-CM4-V1-MR & $3.75 \times 2.5^{\circ}$ & Marti et al. (2005) \\
UBRIS-HadCM3M2 & $3.75 \times 2.5^{\circ}$ & Gordon et al. (2000) \\
\hline
\end{tabular}

Title Page

Abstract

Introduction

Conclusions

References

Tables

Figures

14

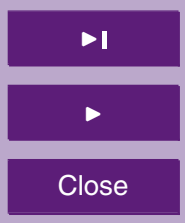

Back

Full Screen / Esc

Printer-friendly Version

Interactive Discussion

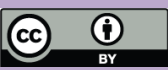




\section{Mid-Holocene vegetation in Europe}

S. Brewer et al.

Table 2. List of experiments performed during this study and associated variables. Temp: monthly temperature; Prec: monthly precipitation; $\mathrm{CO}_{2}$ : Atmospheric concentration; Other: all other climatic parameters. " $0 \mathrm{ka}$ " indicates that the pre-industrial values of that variable were used; " $6 \mathrm{ka}$ " indicates that mid-Holocene values were used.

\begin{tabular}{lcccc}
\hline Experiment & Temp. & Prec. & $\mathrm{CO}_{2}$ conc. & Other \\
\hline PREIND & $0 \mathrm{ka}$ & $0 \mathrm{ka}$ & $0 \mathrm{ka}$ & $0 \mathrm{ka}$ \\
MHL & $6 \mathrm{ka}$ & $6 \mathrm{ka}$ & $6 \mathrm{ka}$ & $6 \mathrm{ka}$ \\
VClim & $6 \mathrm{ka}$ & $6 \mathrm{ka}$ & $0 \mathrm{ka}$ & $6 \mathrm{ka}$ \\
VCO2 & $0 \mathrm{ka}$ & $0 \mathrm{ka}$ & $6 \mathrm{ka}$ & $0 \mathrm{ka}$ \\
VPRC & $0 \mathrm{ka}$ & $6 \mathrm{ka}$ & $6 \mathrm{ka}$ & $6 \mathrm{ka}$ \\
VTEM & $6 \mathrm{ka}$ & $0 \mathrm{ka}$ & $6 \mathrm{ka}$ & $6 \mathrm{ka}$ \\
\hline
\end{tabular}

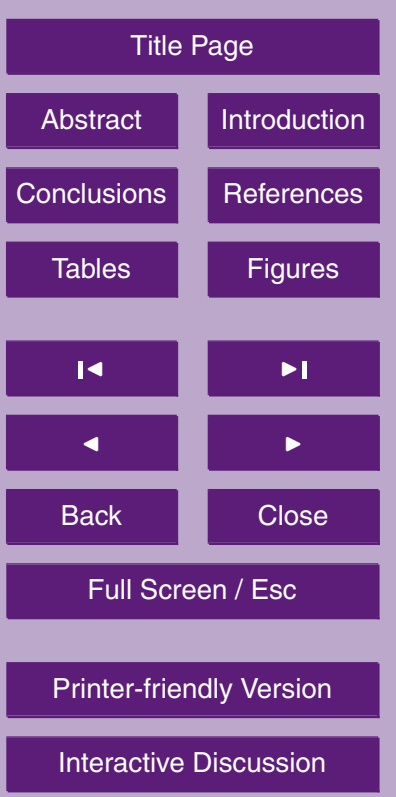


5, 965-1011, 2009

\section{Mid-Holocene vegetation in Europe}

S. Brewer et al.

Table 3. Average changes in simulated productivity and carbon storage for the European continent at the mid-Holocene. NPP: Net primary productivity; CVeg: Vegetation carbon stock; CSoil: Soil carbon; CTotal: Total carbon stock.

\begin{tabular}{lcccc}
\hline Model & NPP $\left({\left.\mathrm{Gt} \mathrm{C} \mathrm{yr}^{-1}\right)}\right.$ CVeg (Gt C) & CSoil (Gt C) & CTotal (Gt C) \\
\hline ECHAM-MPIOM1 & -0.323 & -5.08 & -11.11 & -16.19 \\
GISSmodelE & -0.299 & -4.98 & -10.82 & -15.8 \\
IPSL-CM4-V1-MR & -0.466 & -8.52 & -15.46 & -23.98 \\
HadCM3M2 & -0.454 & -8.02 & 14.38 & -22.39 \\
\hline
\end{tabular}

\section{Title Page}

\section{Abstract}

Introduction

Conclusions

References

Tables

Figures

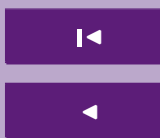

Back

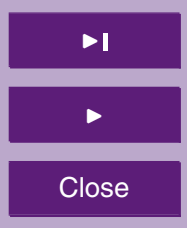

Full Screen / Esc

Printer-friendly Version

Interactive Discussion 


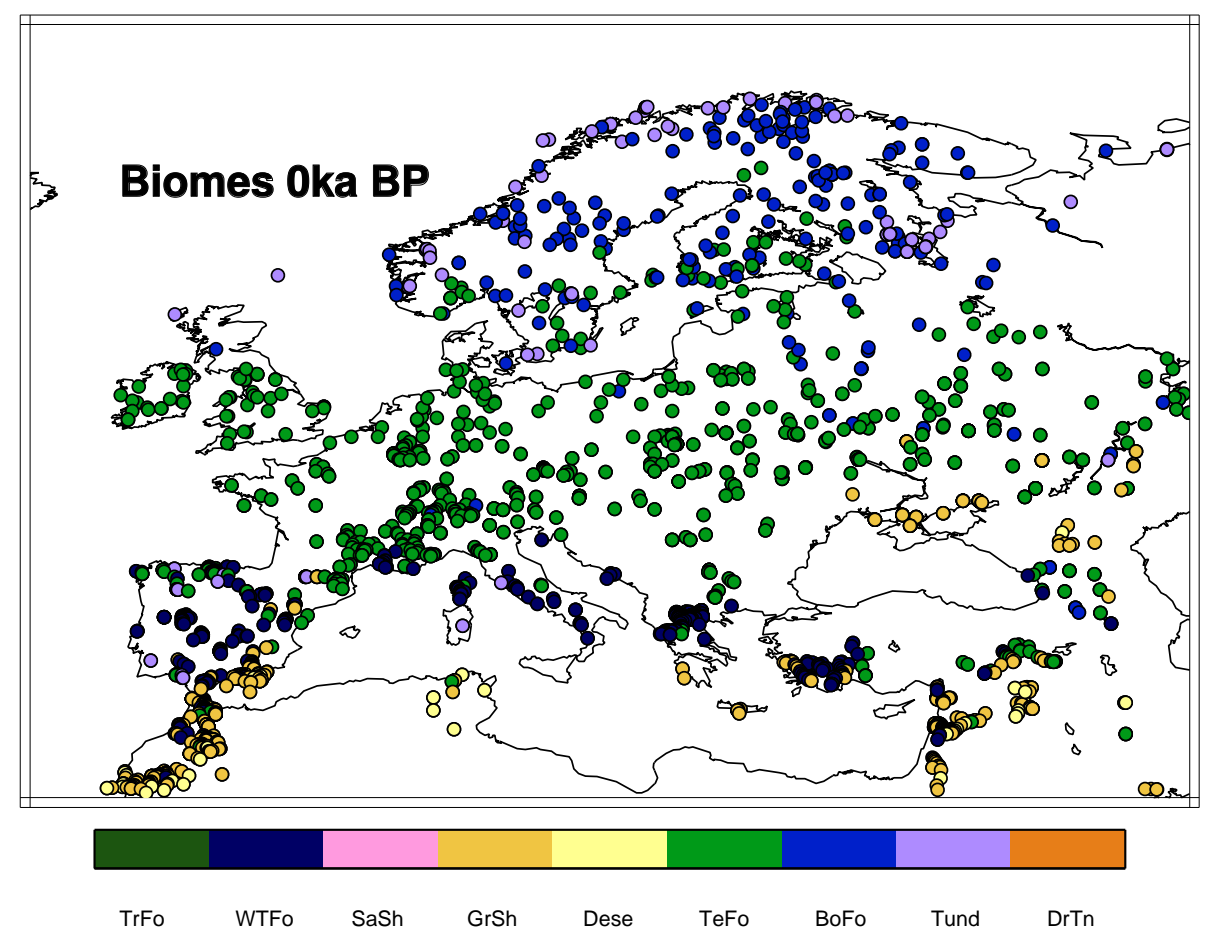

5, 965-1011, 2009

Mid-Holocene vegetation in Europe

S. Brewer et al.

\begin{tabular}{|c|c|}
\hline \multicolumn{2}{|c|}{ Title Page } \\
\hline Abstract & Introduction \\
\hline Conclusions & References \\
\hline Tables & Figures \\
\hline I4 & \\
\hline 4 & $\bullet$ \\
\hline Back & Close \\
\hline Full Screen / Esc
\end{tabular}

Fig. 1. (a) Distribution of biomes in Europe at $0 \mathrm{ka}$. TrFo $=$ Tropical forest; WTFo $=$ Warm temperate forest; SaSh = Savannah/shrubland; GrSh Grassland/Shrubland; Dese = Desert;

Printer-friendly Version TeFo $=$ Temperate forest; BoFo $=$ Boreal forest; Tund $=$ Tundra; DrTn $=$ Dry tundra .

Interactive Discussion

(․) (1) 


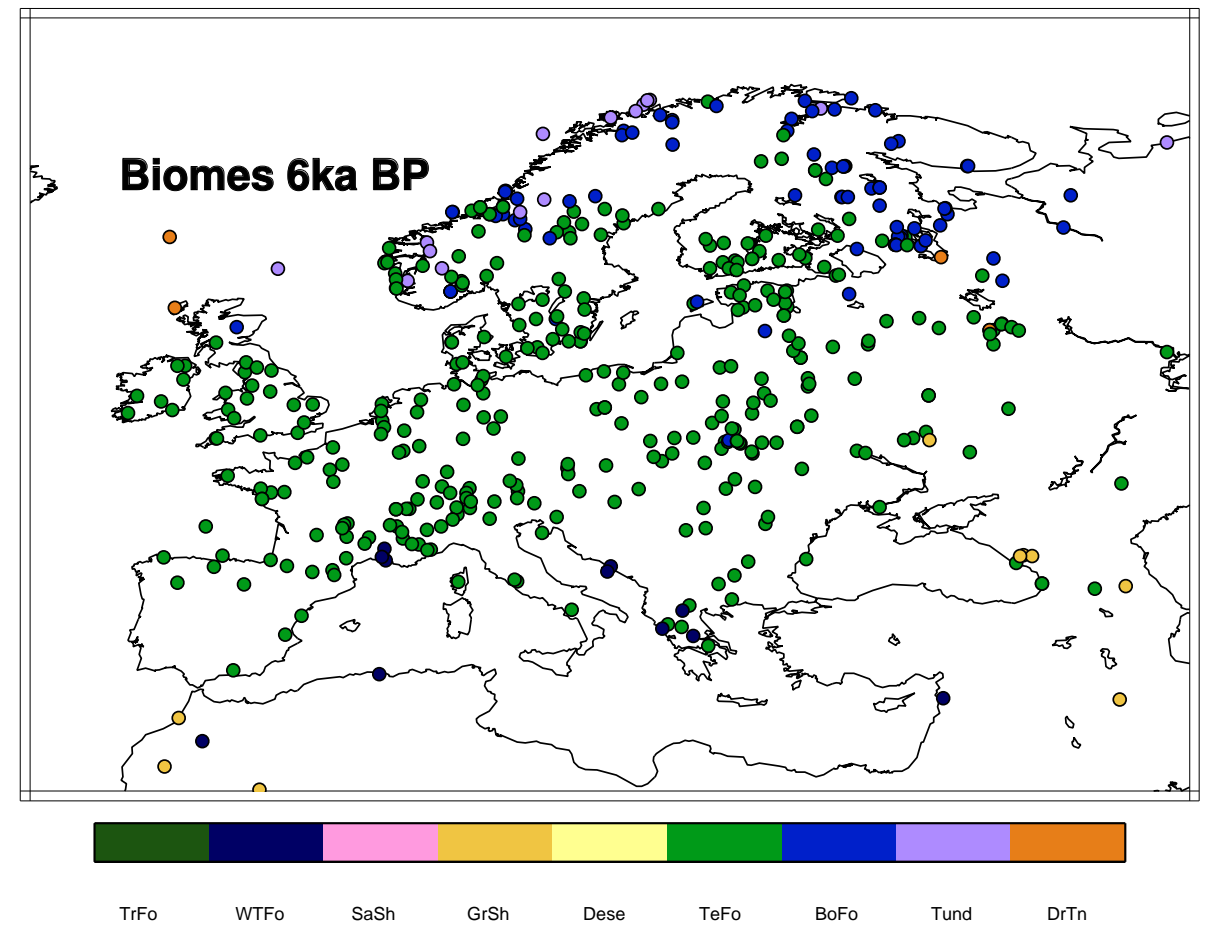

Fig. 1. (b) Distribution of biomes in Europe at the mid-Holocene. See Fig. 1a for caption.
$5,965-1011,2009$

\section{Mid-Holocene vegetation in Europe \\ S. Brewer et al.}

\begin{tabular}{|c|c|}
\hline \multicolumn{2}{|c|}{ Title Page } \\
\hline Abstract & Introduction \\
\hline Conclusions & References \\
\hline Tables & Figures \\
\hline I4 & \\
\hline 4 & $-\mathbf{I}$ \\
\hline Back & Close \\
\hline Full Screen / Esc
\end{tabular}

Printer-friendly Version

Interactive Discussion 


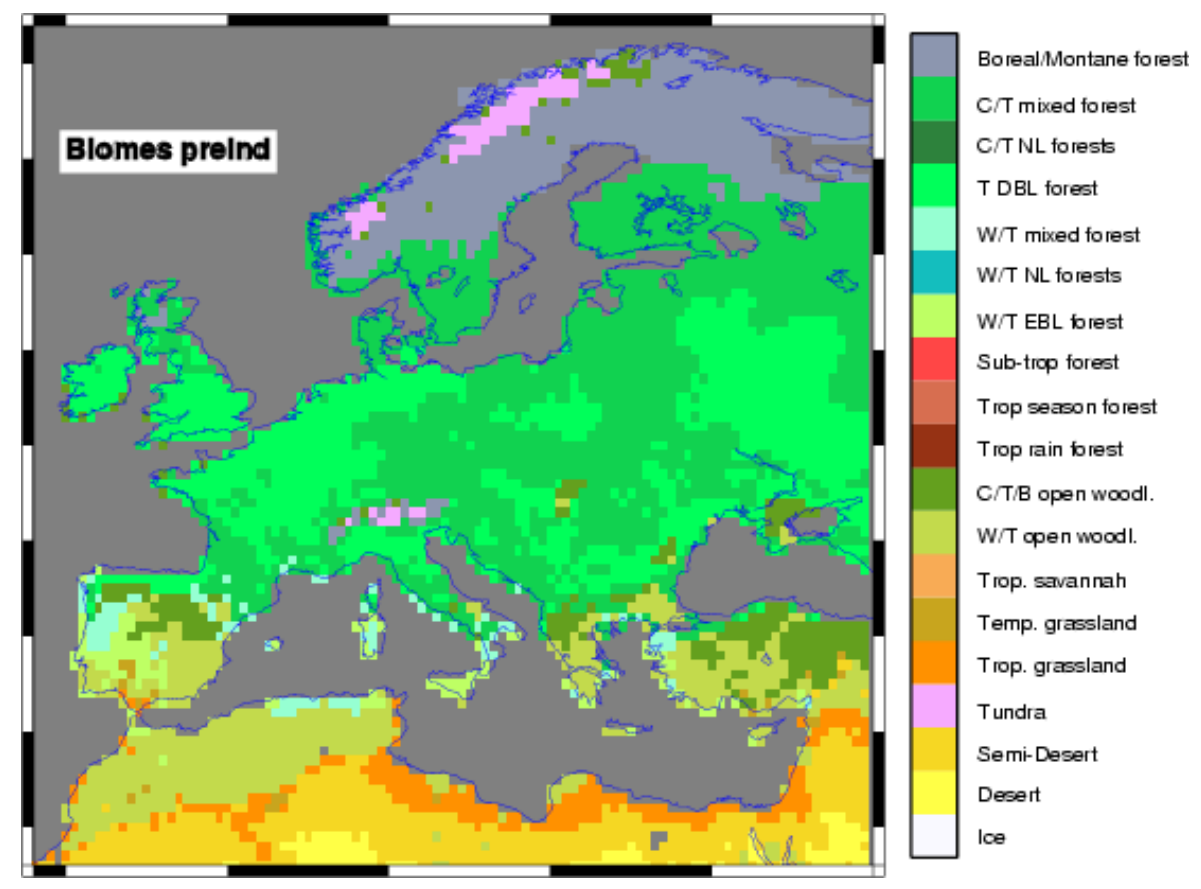

5, 965-1011, 2009

\section{Mid-Holocene vegetation in Europe}

S. Brewer et al.

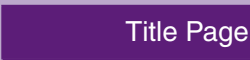

\begin{tabular}{|c|c|}
\hline Abstract & Introduction \\
\hline Conclusions & References \\
\hline Tables & Figures \\
\hline I4 & $\bullet$ \\
\hline 4 & $\triangleright$ \\
\hline Back & Close \\
\hline Full Screen / Esc \\
\hline
\end{tabular}

Fig. 2. Simulated distribution of biomes for the pre-industrial period.

Printer-friendly Version

Interactive Discussion

(a) (1) 
5, 965-1011, 2009

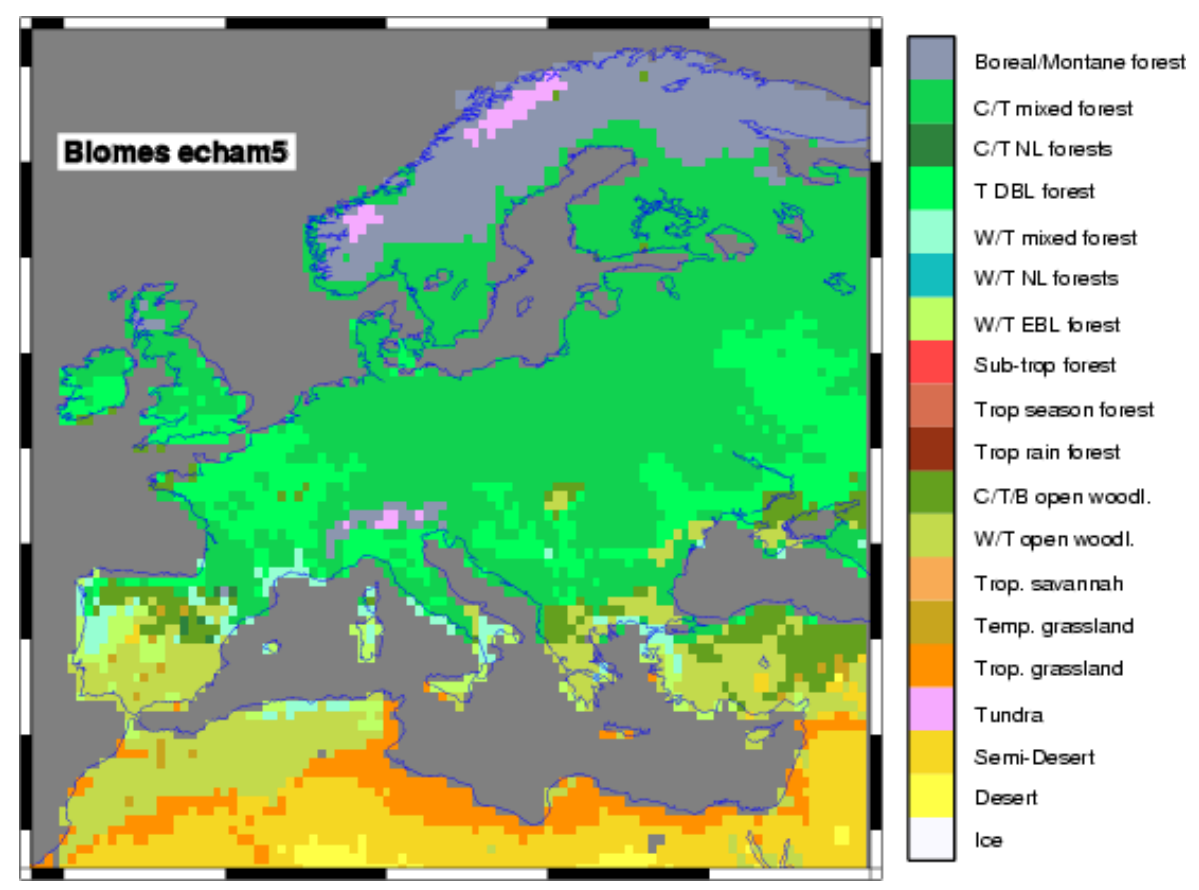

\section{Mid-Holocene vegetation in Europe}

S. Brewer et al.

Title Page

\begin{tabular}{|c|c|}
\hline Abstract & Introduction \\
\hline Conclusions & References \\
\hline Tables & Figures \\
\hline I4 & $\triangleright$ \\
\hline 4 & $\triangleright$ \\
\hline Back & Close \\
\hline Full Screen / Esc
\end{tabular}

Fig. 3. (a) Simulated distribution of biomes for the mid-Holocene with input from the ECHAM5MPIOM1 GCM. See Fig. 2 for details.

Printer-friendly Version

Interactive Discussion 


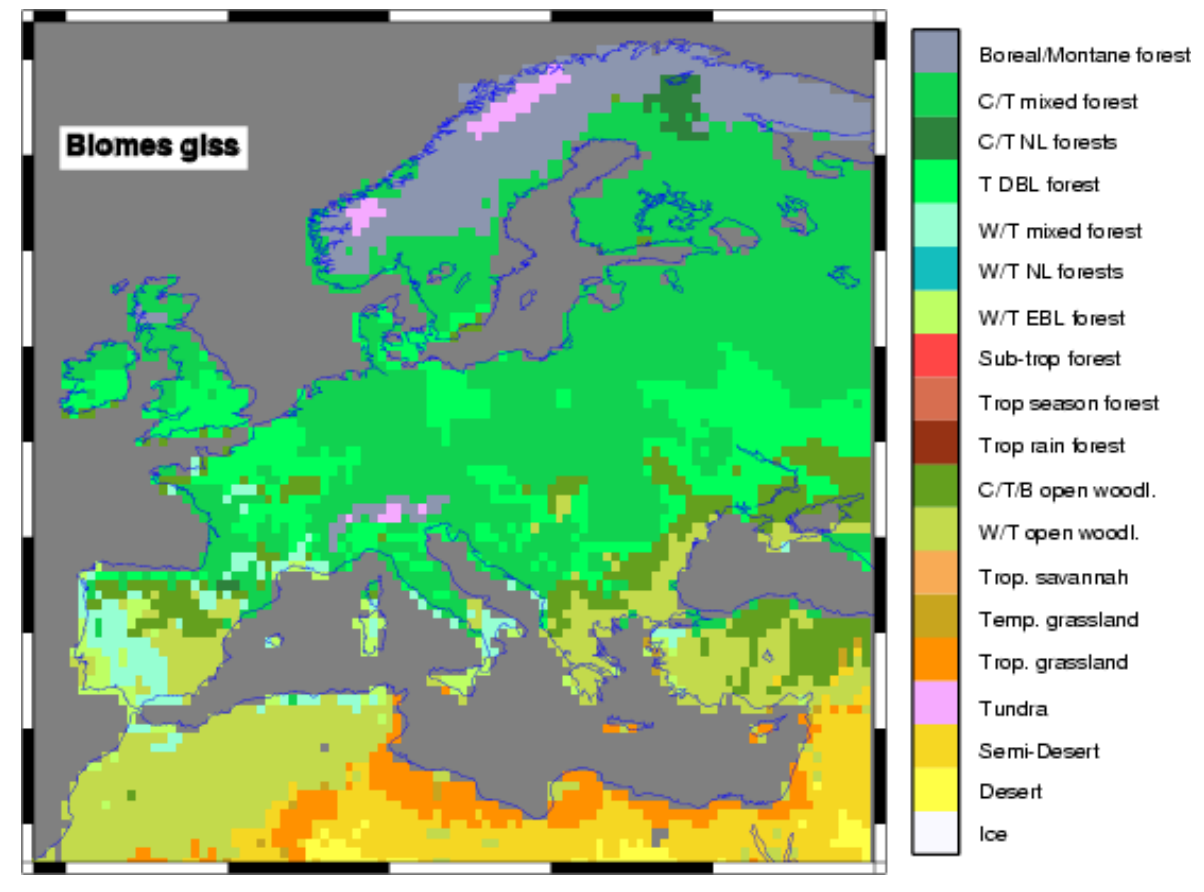

5, 965-1011, 2009

\section{Mid-Holocene vegetation in Europe}

S. Brewer et al.

\begin{tabular}{|c|c|}
\hline \multicolumn{2}{|c|}{ Title Page } \\
\hline Abstract & Introduction \\
\hline Conclusions & References \\
\hline Tables & Figures \\
\hline I4 & \\
\hline 4 & $-\mathbf{I}$ \\
\hline Back & Close \\
\hline Full Screen / Esc
\end{tabular}

Printer-friendly Version

Interactive Discussion
Fig. 3. (b) Simulated distribution of biomes for the mid-Holocene with input from the GISSmodelE GCM. See Fig. 2 for details. 


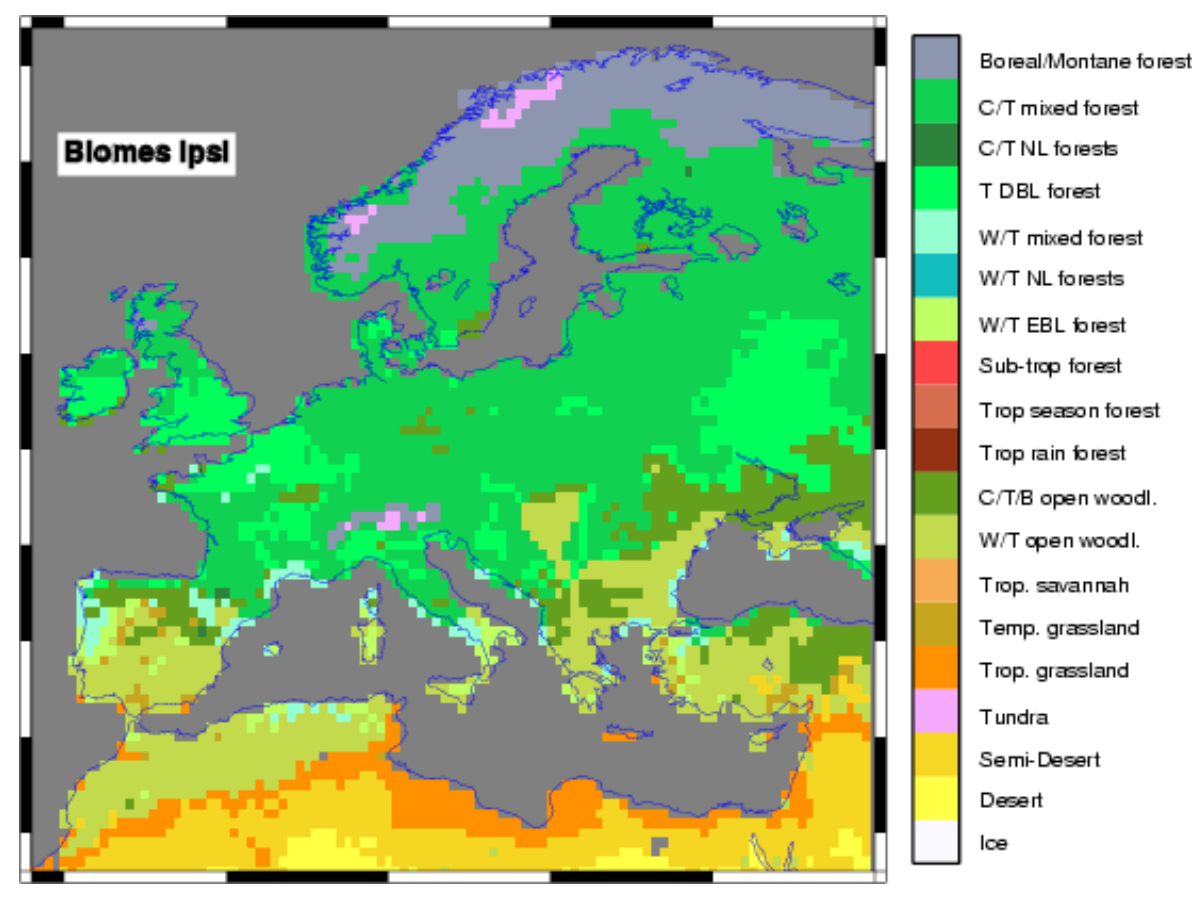

5, 965-1011, 2009

\section{Mid-Holocene vegetation in Europe}

S. Brewer et al.

\begin{tabular}{|c|c|}
\hline \multicolumn{2}{|c|}{ Title Page } \\
\hline Abstract & Introduction \\
\hline Conclusions & References \\
\hline Tables & Figures \\
\hline I4 & \\
\hline 4 & $-\mathbf{I}$ \\
\hline Back & Close \\
\hline Full Screen / Esc
\end{tabular}

Printer-friendly Version

Interactive Discussion
Fig. 3. (c) Simulated distribution of biomes for the mid-Holocene with input from the IPSL-CM4V1-MR GCM. See Fig. 2 for details.

$\mathrm{C} / \mathrm{T}$ mixed forest

T DBL forest

$w / T$ mixed forest

Trop rain torest

C/T/B open woodl.

W/T open wood.

rop. grassland

Semi-Desert

loe 


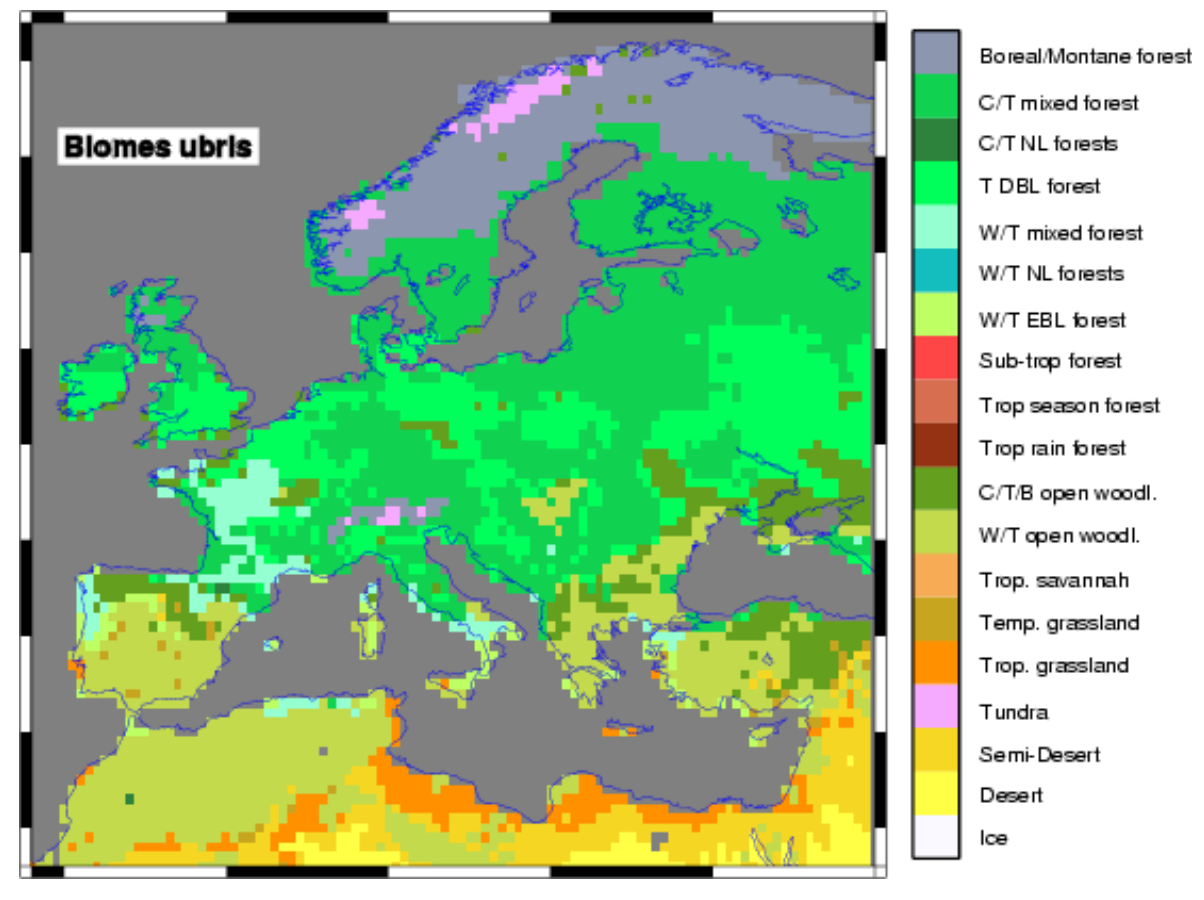

5, 965-1011, 2009

\section{Mid-Holocene vegetation in Europe}

S. Brewer et al.

Title Page

\begin{tabular}{|c|c|}
\hline Abstract & Introduction \\
\hline Conclusions & References \\
\hline Tables & Figures \\
\hline I4 & $\triangleright \mathbf{I}$ \\
\hline 4 & $\triangleright$ \\
\hline Back & Close \\
\hline Full Screen / Esc \\
\hline
\end{tabular}

Fig. 3. (d) Simulated distribution of biomes for the mid-Holocene with input from the UBrisHadCM3M2 GCM. See Fig. 2 for details.

Printer-friendly Version

Interactive Discussion

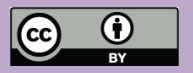




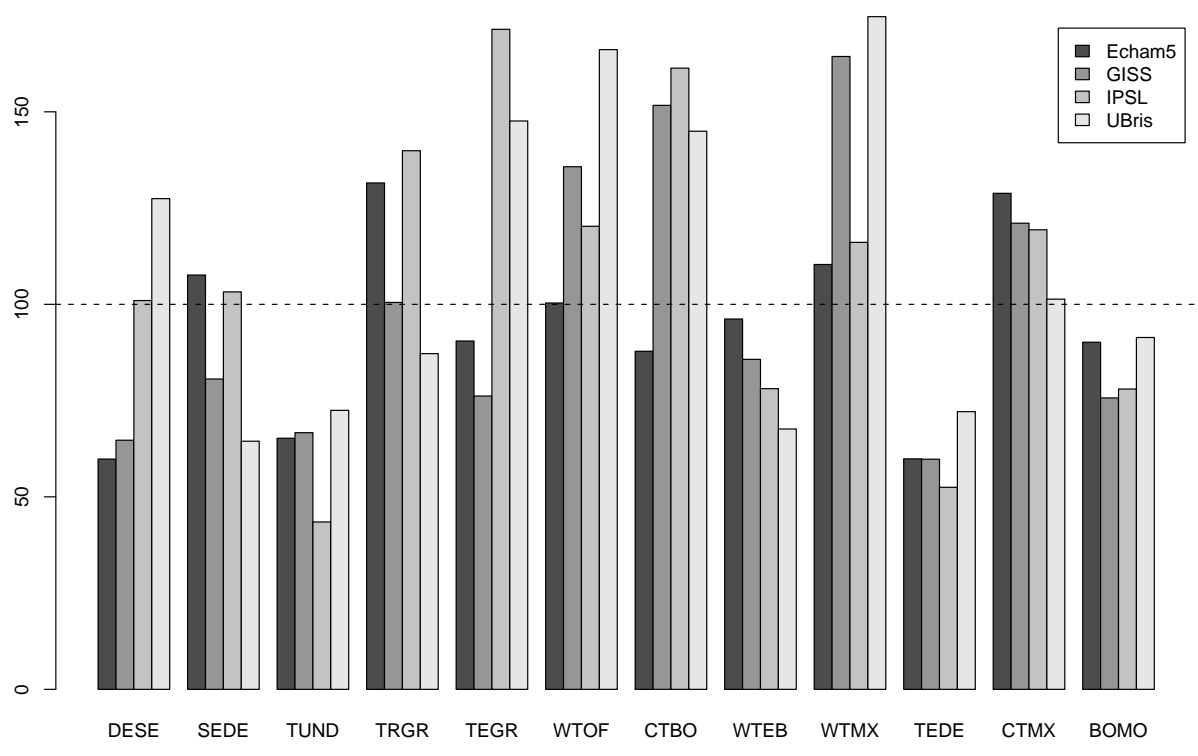

Fig. 4. Mid-Holocene cover of simulated biomes as as percentages of modern cover. DESE = Desert; SEDE = Semi-desert; TUND = Tundra; TRGR = Tropical grassland; TEGR $=$ Temperate grassland; WTOF $=$ Warm temperate open forest; $\mathrm{CTBO}=$ Cool temperate boreal forest; WTEB $=$ Warm temperate evergreen broadleaved forest; WTMX $=$ Warm temperate mixed forest; TEDE $=$ Temperate deciduous forest; CTMX = Cool temperate mixed; $\mathrm{BOMO}=$ Boreal montane forest.

\section{Mid-Holocene} vegetation in Europe

S. Brewer et al.

\begin{tabular}{|c|c|}
\hline \multicolumn{2}{|c|}{ Title Page } \\
\hline Abstract & Introduction \\
\hline Conclusions & References \\
\hline Tables & Figures \\
\hline I4 & \\
\hline 4 & $-\mathbf{I}$ \\
\hline Back & Close \\
\hline Full Screen / Esc
\end{tabular}

Printer-friendly Version

Interactive Discussion 
5, 965-1011, 2009

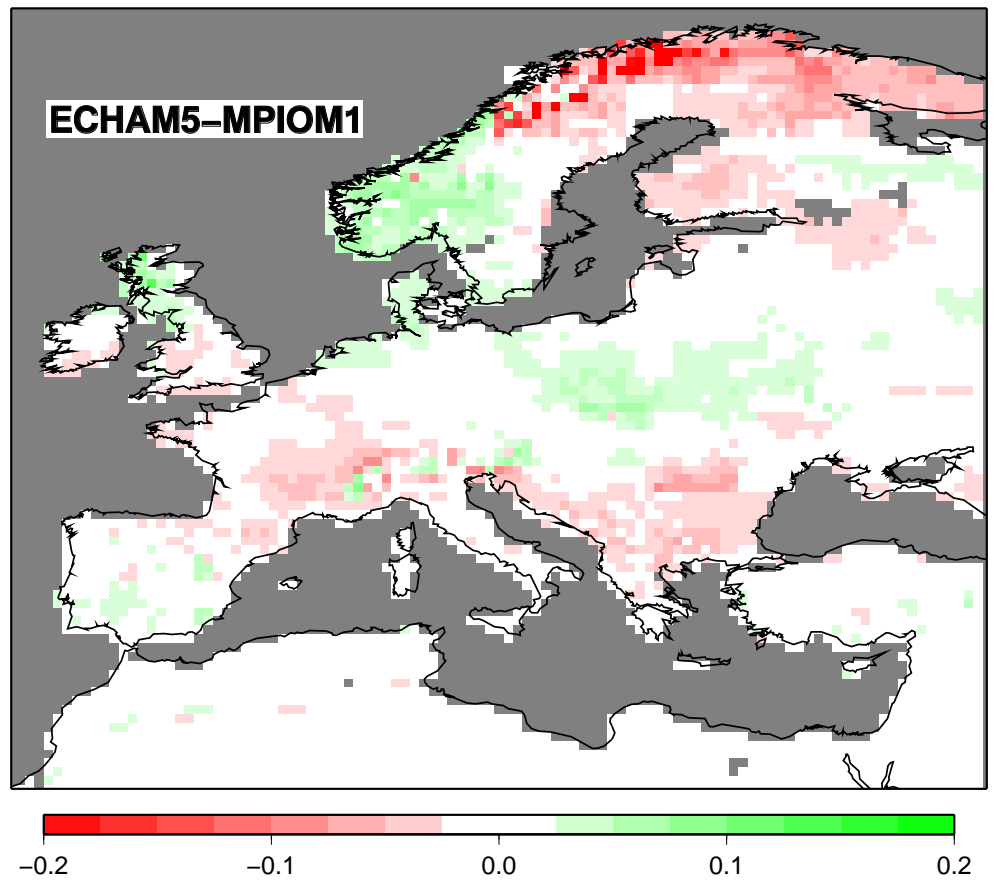

\section{Mid-Holocene vegetation in Europe \\ S. Brewer et al.}

\begin{tabular}{|c|c|}
\hline \multicolumn{2}{|c|}{ Title Page } \\
\hline Abstract & Introduction \\
\hline Conclusions & References \\
\hline Tables & Figures \\
\hline I4 & $\bullet \mathbf{I}$ \\
\hline 4 & $\bullet$ \\
\hline Back & Close \\
\hline Full Screen / Esc
\end{tabular}

Fig. 5. (a) Change in soil water availability at the mid-Holocene (in $\mathrm{mm} / \mathrm{m}$ ) for the ECHAM5MPIOM simulation.

Printer-friendly Version

Interactive Discussion 
5, 965-1011, 2009

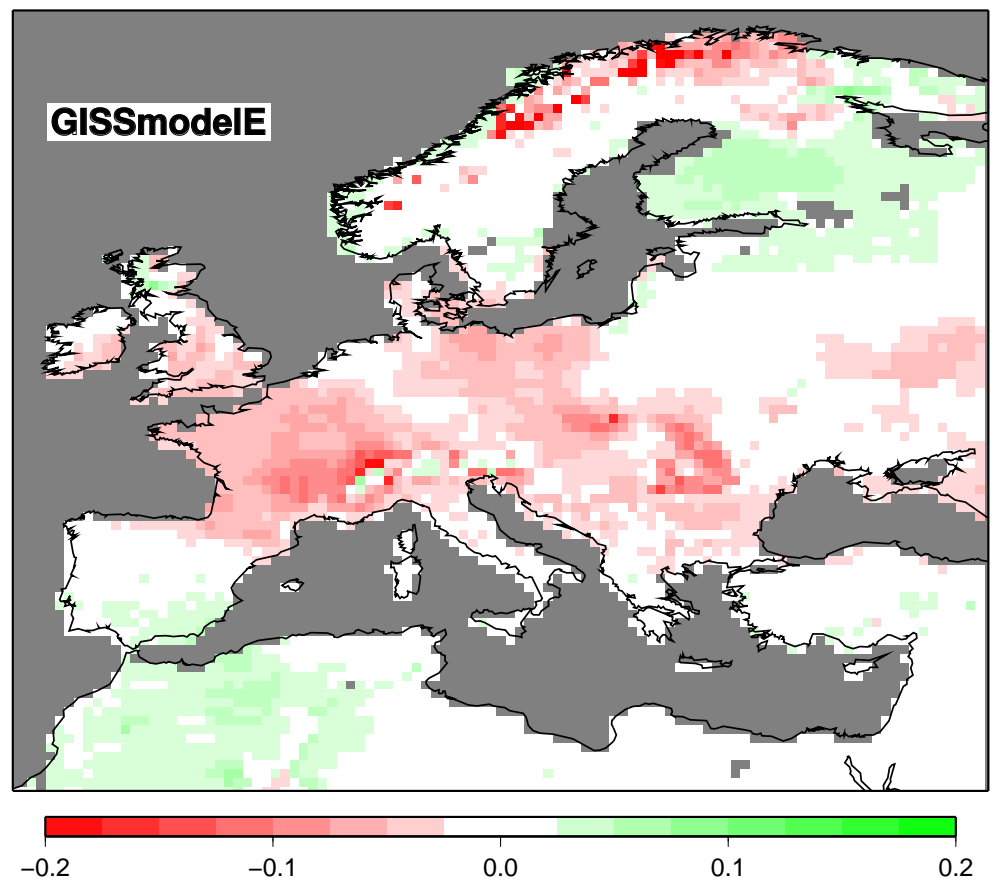

\section{Mid-Holocene vegetation in Europe \\ S. Brewer et al.}

\begin{tabular}{|c|c|}
\hline \multicolumn{2}{|c|}{ Title Page } \\
\hline Abstract & Introduction \\
\hline Conclusions & References \\
\hline Tables & Figures \\
\hline I4 & $\bullet \mathbf{I}$ \\
\hline 4 & $\bullet$ \\
\hline Back & Close \\
\hline Full Screen / Esc
\end{tabular}

Fig. 5. (b) Change in soil water availability at the mid-Holocene (in $\mathrm{mm} / \mathrm{m}$ ) for the GISSmodelE simulation.

Printer-friendly Version

Interactive Discussion 
5, 965-1011, 2009

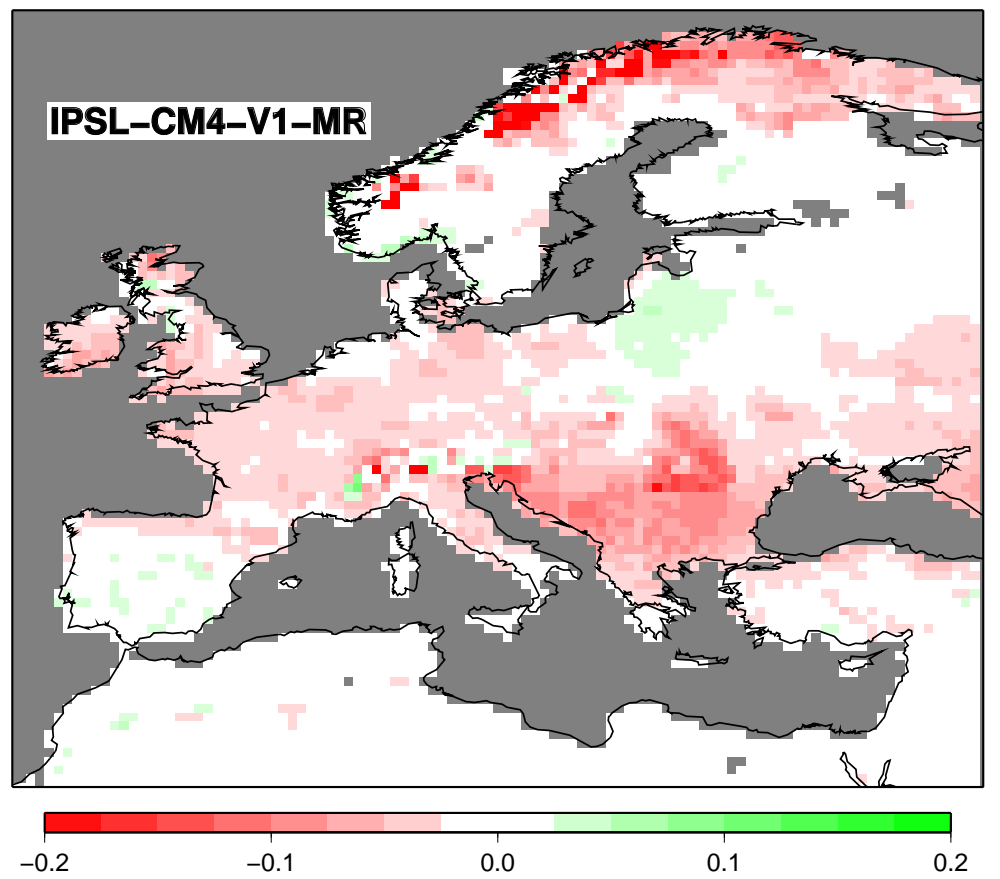

\section{Mid-Holocene vegetation in Europe \\ S. Brewer et al.}

\begin{tabular}{|c|c|}
\hline \multicolumn{2}{|c|}{ Title Page } \\
\hline Abstract & Introduction \\
\hline Conclusions & References \\
\hline Tables & Figures \\
\hline I4 & \\
\hline 4 & $\bullet$ \\
\hline Back & Close \\
\hline Full Screen / Esc
\end{tabular}

Fig. 5. (c) Change in soil water availability at the mid-Holocene (in $\mathrm{mm} / \mathrm{m}$ ) for the IPSL-CM4V1-MR simulation.

Printer-friendly Version

Interactive Discussion 
5, 965-1011, 2009

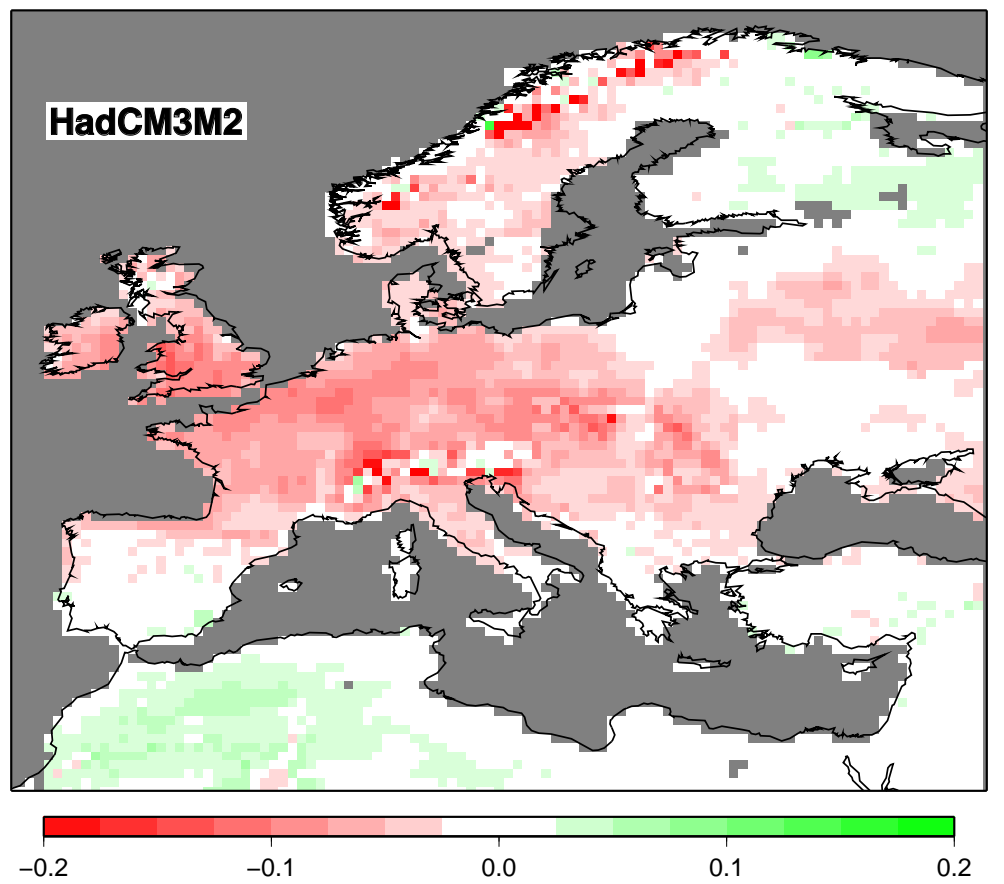

\section{Mid-Holocene vegetation in Europe \\ S. Brewer et al.}

\begin{tabular}{|c|c|}
\hline \multicolumn{2}{|c|}{ Title Page } \\
\hline Abstract & Introduction \\
\hline Conclusions & References \\
\hline Tables & Figures \\
\hline I4 & \\
\hline 4 & $\bullet$ \\
\hline Back & Close \\
\hline Full Screen / Esc
\end{tabular}

Fig. 5. (d) Change in soil water availability at the mid-Holocene (in $\mathrm{mm} / \mathrm{m}$ ) for the UBRISHadCM3M2 simulation.

Printer-friendly Version

Interactive Discussion 
5, 965-1011, 2009
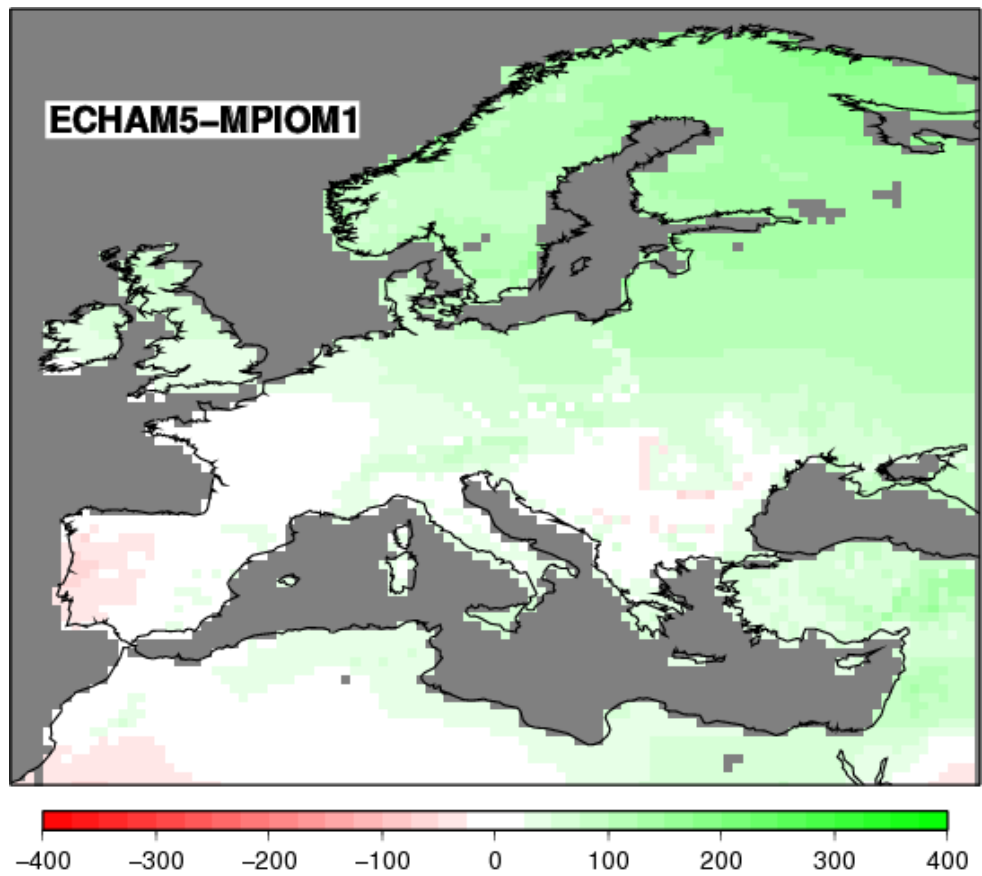

\section{Mid-Holocene vegetation in Europe}

S. Brewer et al.

\begin{tabular}{|c|c|}
\hline \multicolumn{2}{|c|}{ Title Page } \\
\hline Abstract & Introduction \\
\hline Conclusions & References \\
\hline Tables & Figures \\
\hline I4 & \\
\hline 4 & $\triangleright \mathbf{I}$ \\
\hline Back & Close \\
\hline Full Screen / Esc
\end{tabular}

Fig. 6. (a) Changes in growing season length, calculated as the sum of degree days over $5^{\circ} \mathrm{C}$ (GDD5) for the ECHAM5-MPIOM simulation.

Printer-friendly Version

Interactive Discussion 
5, 965-1011, 2009

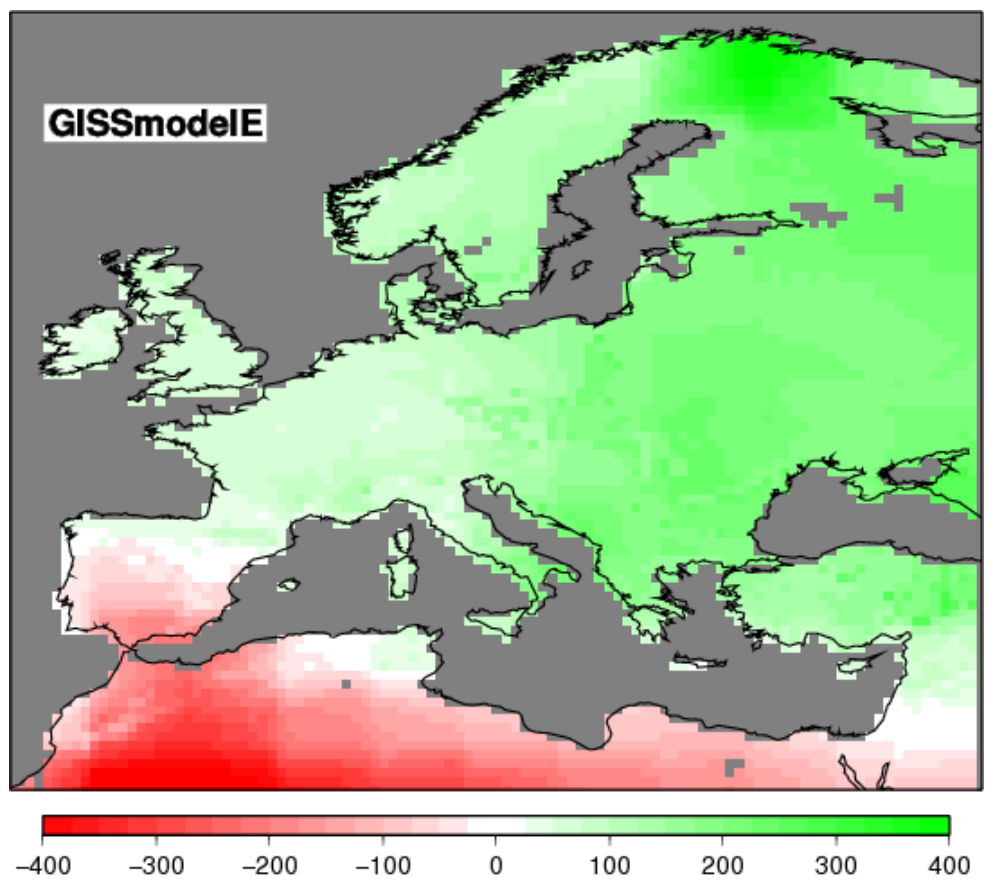

\section{Mid-Holocene vegetation in Europe \\ S. Brewer et al.}

\begin{tabular}{|c|c|}
\hline \multicolumn{2}{|c|}{ Title Page } \\
\hline Abstract & Introduction \\
\hline Conclusions & References \\
\hline Tables & Figures \\
\hline I4 & \\
\hline 4 & $\bullet$ \\
\hline Back & Close \\
\hline Full Screen / Esc
\end{tabular}

Fig. 6. (b) Changes in growing season length, calculated as the sum of degree days over $5^{\circ} \mathrm{C}$ (GDD5) for the GISSmodelE simulation.

Printer-friendly Version

Interactive Discussion 
5, 965-1011, 2009

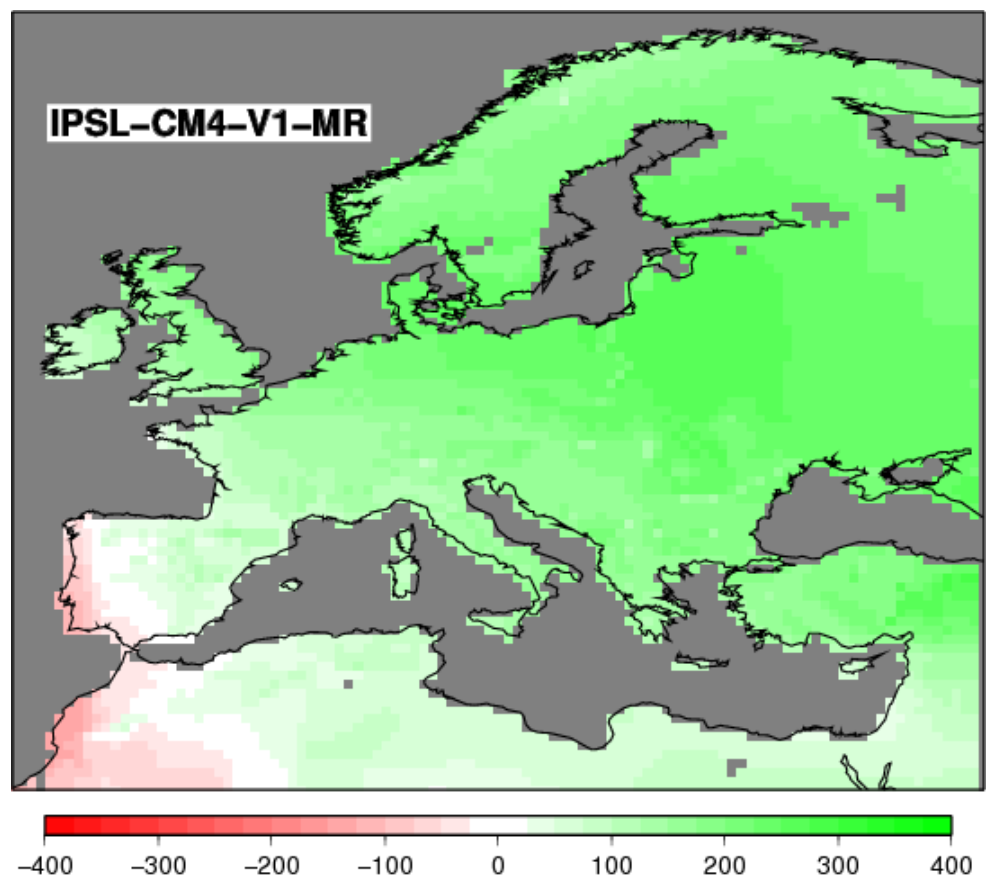

\section{Mid-Holocene vegetation in Europe \\ S. Brewer et al.}

\begin{tabular}{|c|c|}
\hline \multicolumn{2}{|c|}{ Title Page } \\
\hline Abstract & Introduction \\
\hline Conclusions & References \\
\hline Tables & Figures \\
\hline I4 & \multicolumn{1}{|c|}{} \\
\hline 4 & $\triangleright$ \\
\hline Back & Close \\
\hline Full Screen / Esc
\end{tabular}

Fig. 6. (c) Changes in growing season length, calculated as the sum of degree days over $5^{\circ} \mathrm{C}$ (GDD5) for the IPSL-CM4-V1-MR simulation.

Printer-friendly Version

Interactive Discussion 
5, 965-1011, 2009

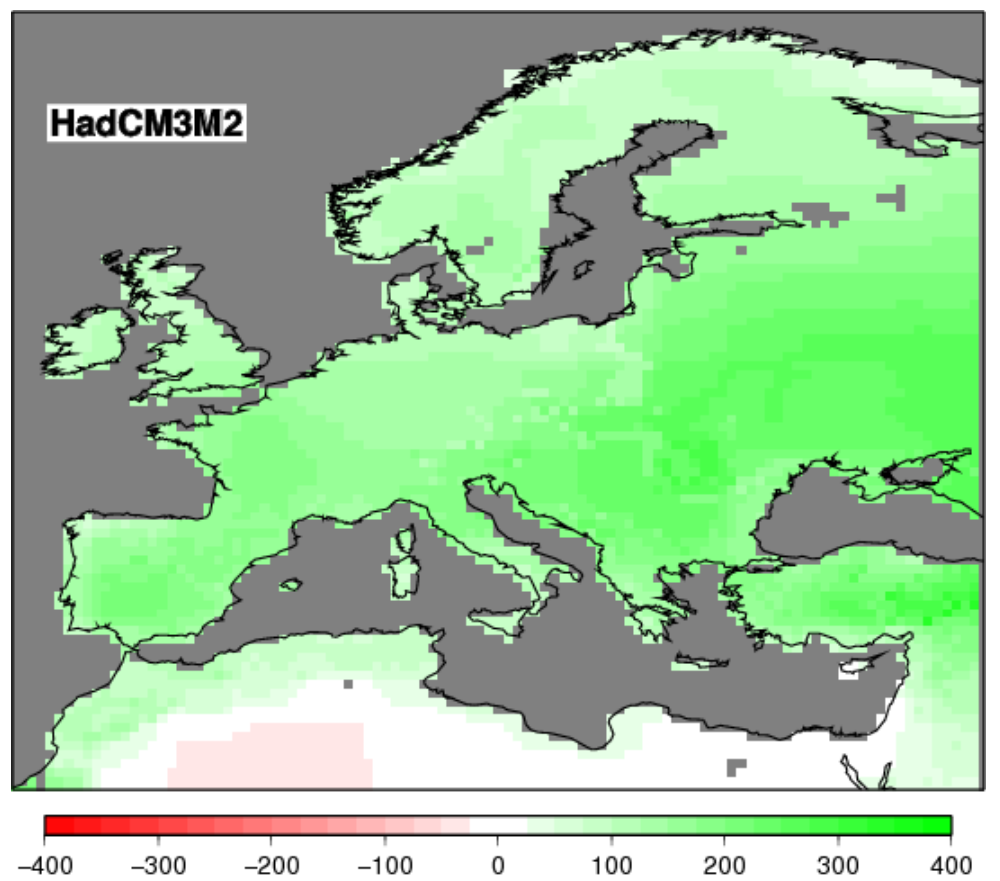

\section{Mid-Holocene vegetation in Europe \\ S. Brewer et al.}

\begin{tabular}{|c|c|}
\hline \multicolumn{2}{|c|}{ Title Page } \\
\hline Abstract & Introduction \\
\hline Conclusions & References \\
\hline Tables & Figures \\
\hline I4 & \multicolumn{1}{|c|}{} \\
\hline 4 & $\triangleright$ \\
\hline Back & Close \\
\hline Full Screen / Esc
\end{tabular}

Fig. 6. (d) Changes in growing season length, calculated as the sum of degree days over $5^{\circ} \mathrm{C}$ (GDD5) for the UBRIS-HadCM3M2 simulation.

Printer-friendly Version

Interactive Discussion 


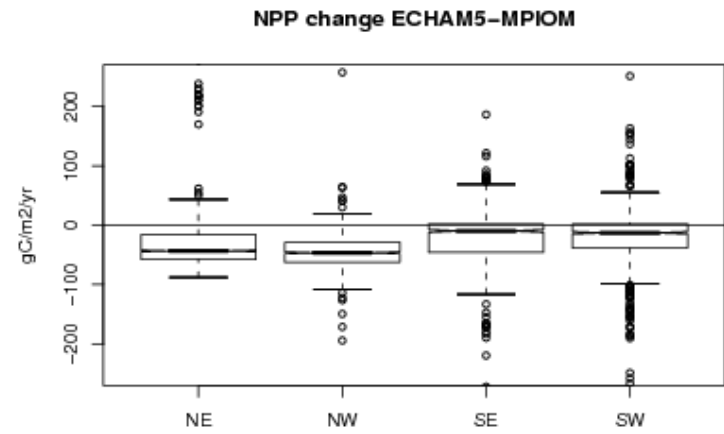

(a)

\section{NPP change IPSL-CM4-V1-MR}

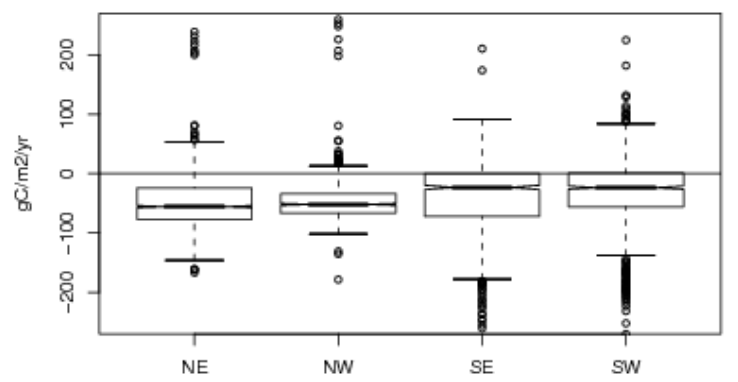

(c)

Fig. 7. Regional productivity changes simulated from the four GCM outputs. The thick black line is the median value, the boxes represent the 25th and 75th percentile, and the bars represent the limits of the data. Outliers are shown as points. (a) ECHAM5-MPIOM1; (b) GISSmodeIE; (c) IPSL-CM4-V1-MR; (d) UBris-HadCM3M2.

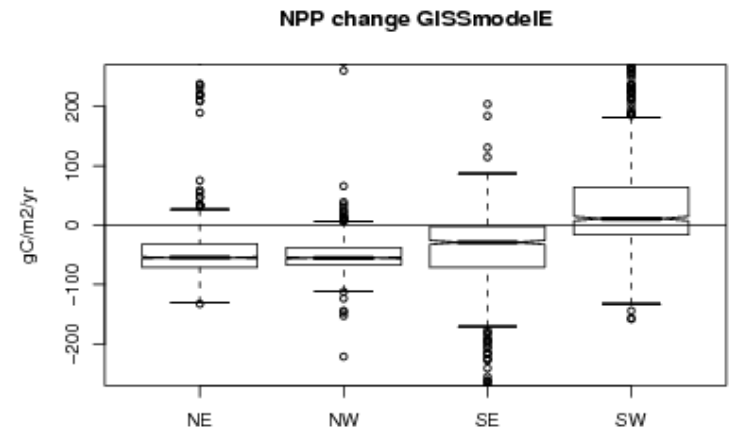

(b)

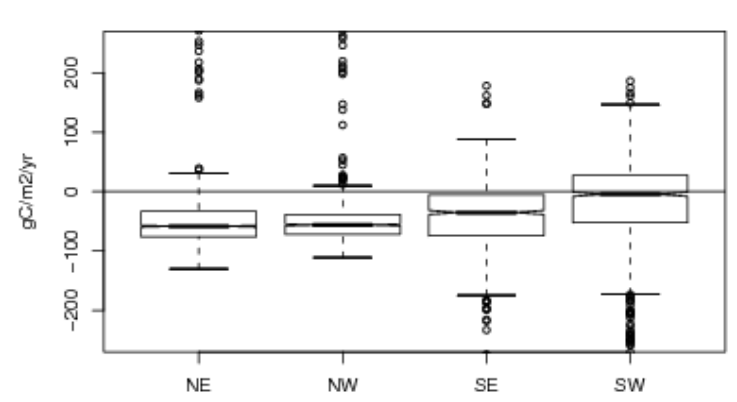

(d)
5, 965-1011, 2009

\section{Mid-Holocene vegetation in Europe}

S. Brewer et al.

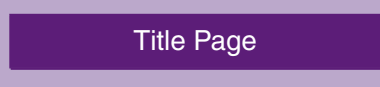

\section{Abstract}

Introduction

Conclusions

References

Tables

Figures

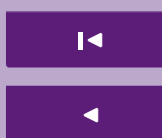

Back

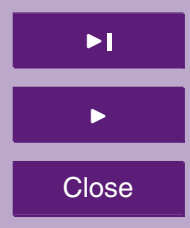

Full Screen / Esc

Printer-friendly Version

Interactive Discussion 
Climatology ECHAM5 NW

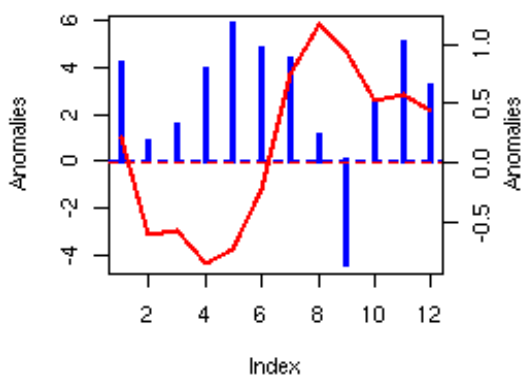

Index

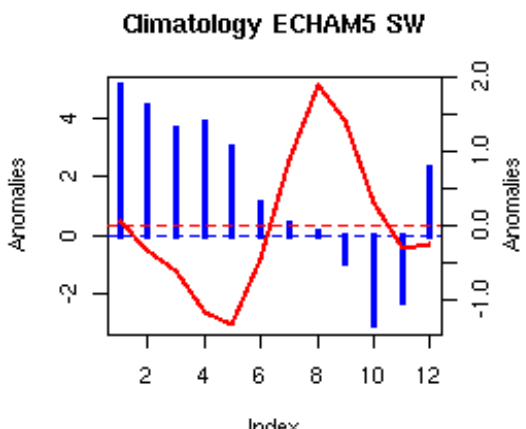

Index

\section{Climatology ECHAM5 NE}

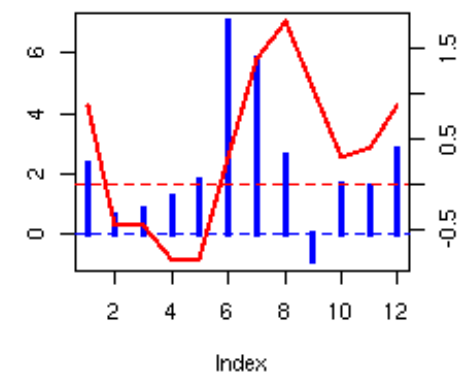

Climatology ECHAM5 SE

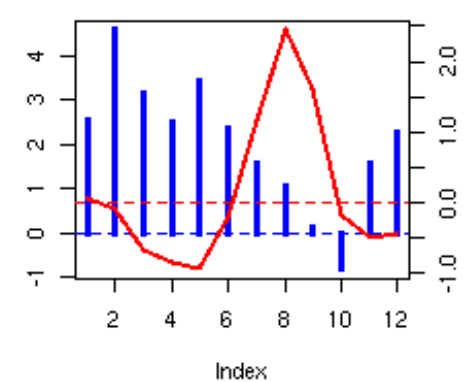

Fig. 8. (a) Anomaly climatologies for the four regions of Europe simulated by ECHAM5MPIOM1. Monthly anomalies are shown for temperature (red line) and precipitation (blue bars).

5, 965-1011, 2009

\section{Mid-Holocene vegetation in Europe}

S. Brewer et al.

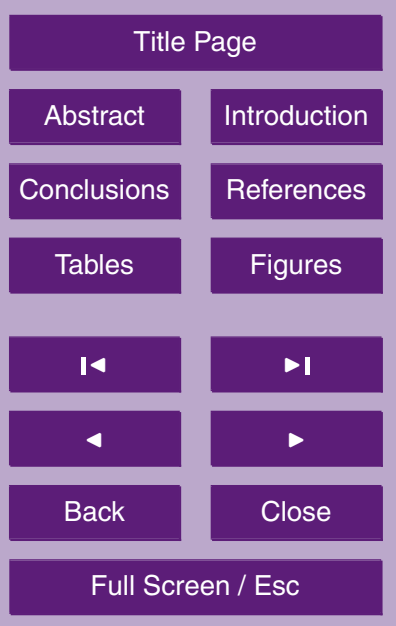

Printer-friendly Version

Interactive Discussion 

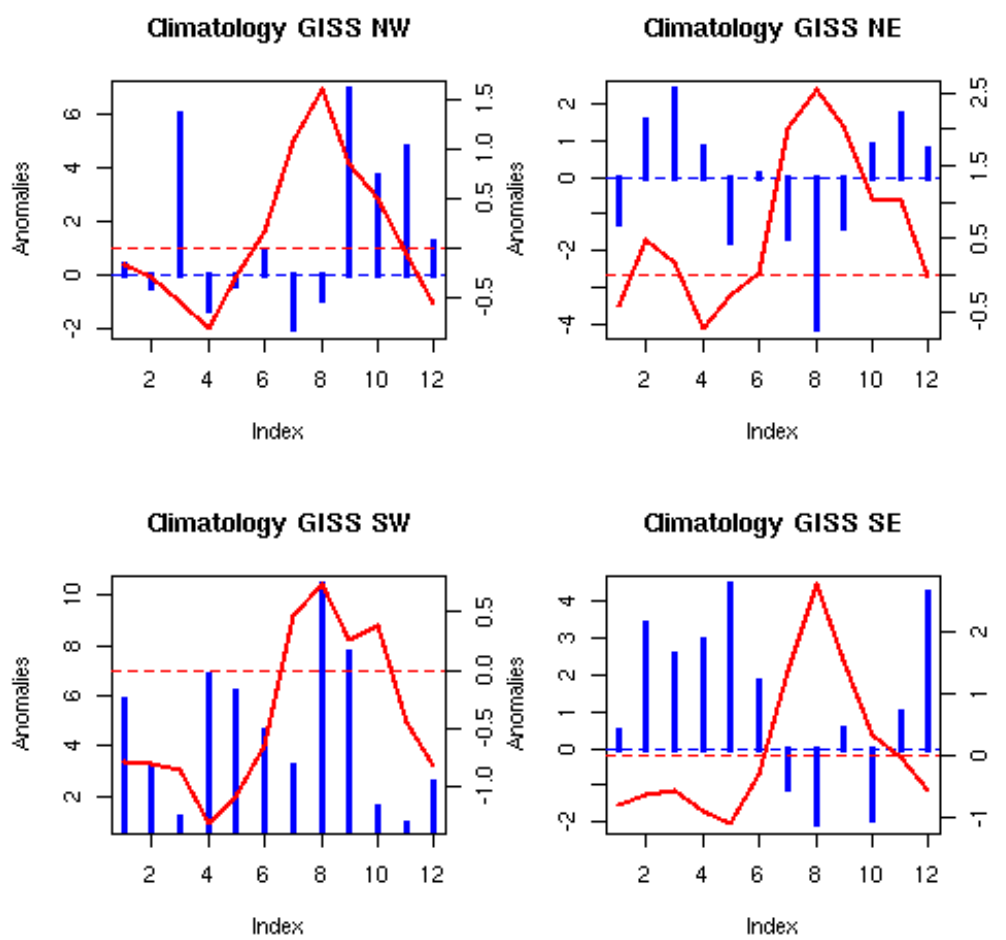

Fig. 8. (b) Anomaly climatologies for the four regions of Europe simulated by GISSmodelE. Monthly anomalies are shown for temperature (red line) and precipitation (blue bars).
5, 965-1011, 2009

\section{Mid-Holocene vegetation in Europe}

S. Brewer et al.

\begin{tabular}{|c|c|}
\hline \multicolumn{2}{|c}{ Title Page } \\
\hline Abstract & Introduction \\
\hline Conclusions & References \\
\hline Tables & Figures \\
\hline I4 & I \\
\hline 4 & $>$ \\
\hline Back & Close \\
\hline Full Screen / Esc
\end{tabular}

Printer-friendly Version

Interactive Discussion 
Climatology IPSL NW

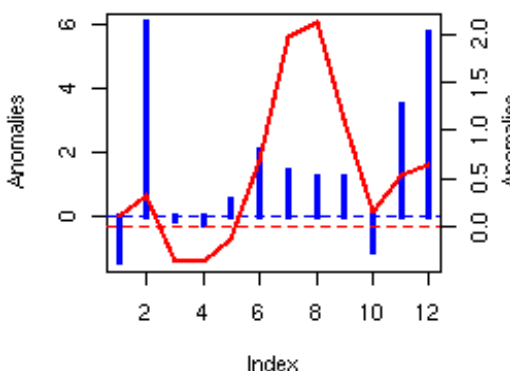

Index

Climatology IPSL SW

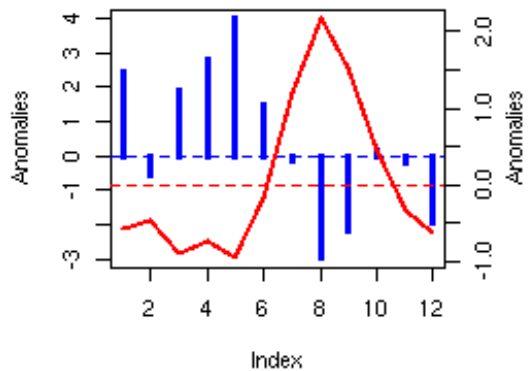

Index
Climatology IPSL NE

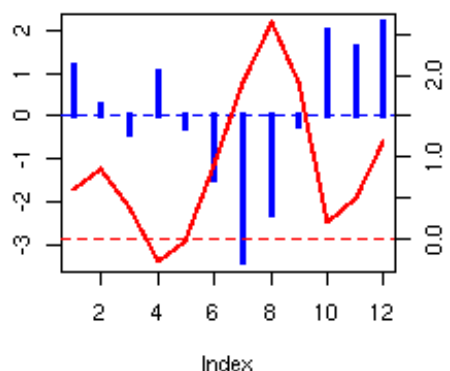

Climatology IPSL SE

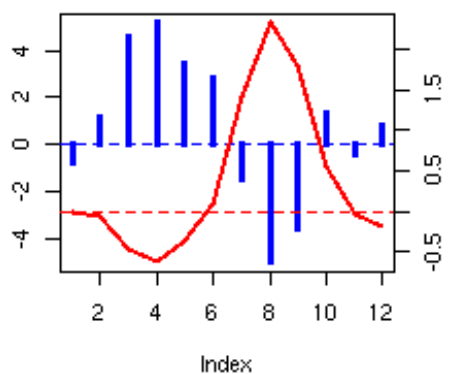

Index

\section{Mid-Holocene vegetation in Europe \\ S. Brewer et al.}

\begin{tabular}{|c|c|}
\hline \multicolumn{2}{|c|}{ Title Page } \\
\hline Abstract & Introduction \\
\hline Conclusions & References \\
\hline Tables & Figures \\
\hline I4 & \\
\hline 4 & $-\mathbf{I}$ \\
\hline Back & Close \\
\hline Full Screen / Esc
\end{tabular}

Printer-friendly Version

Interactive Discussion
Fig. 8. (c) Anomaly climatologies for the four regions of Europe simulated by IPSL-CM4-V1MR. Monthly anomalies are shown for temperature (red line) and precipitation (blue bars). 

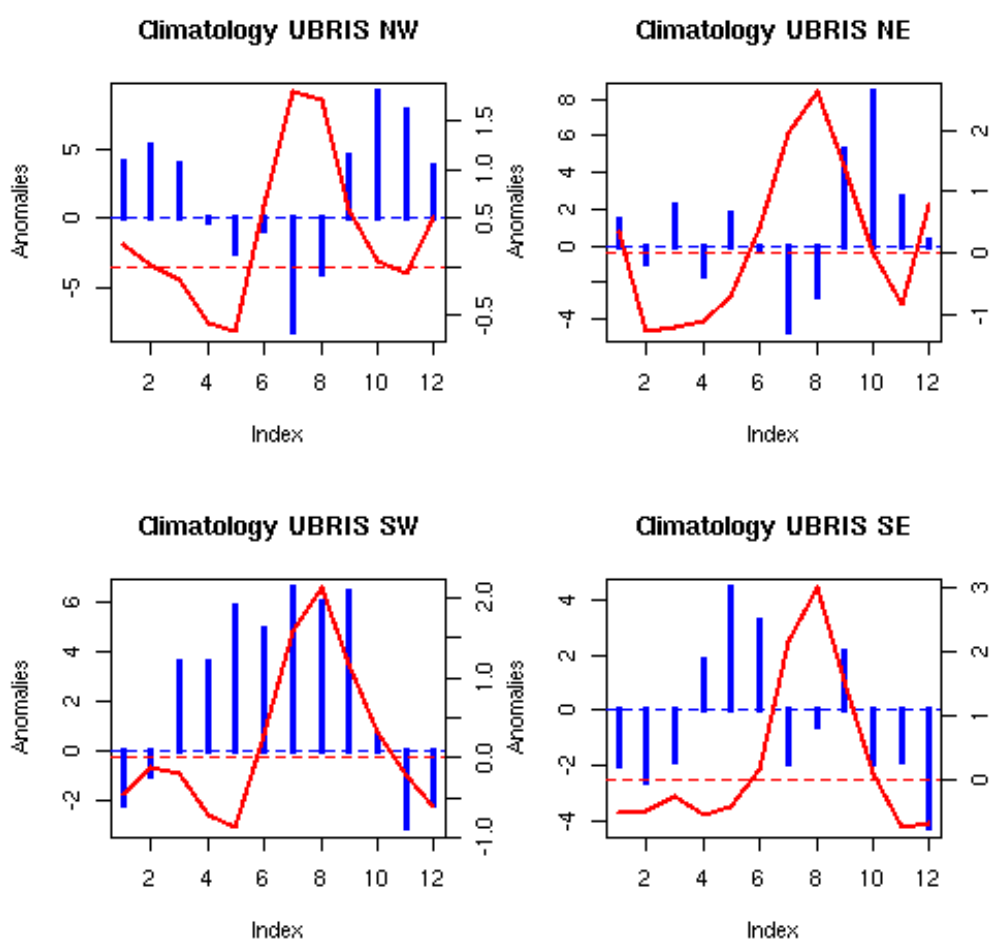

Fig. 8. (d) Anomaly climatologies for the four regions of Europe simulated by UBRISHadCM3M2. Monthly anomalies are shown for temperature (red line) and precipitation (blue bars).
5, 965-1011, 2009

\section{Mid-Holocene vegetation in Europe}

S. Brewer et al.

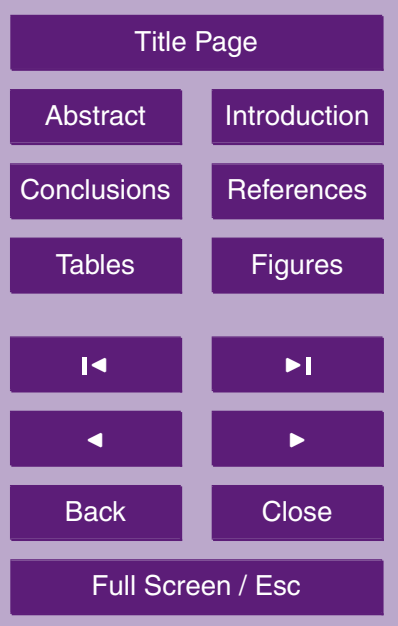

Printer-friendly Version

Interactive Discussion 
Sensitivity NW

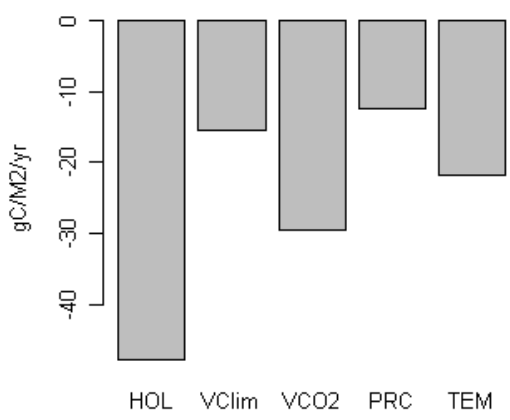

Sensitivity SW

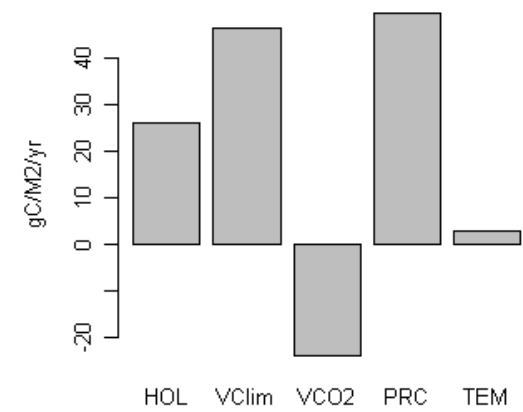

Sensitivity NE

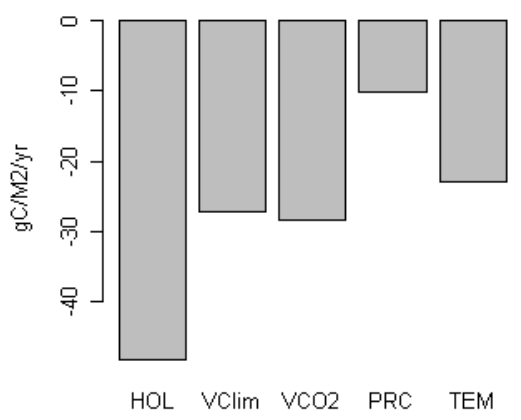

Sensitivity SE

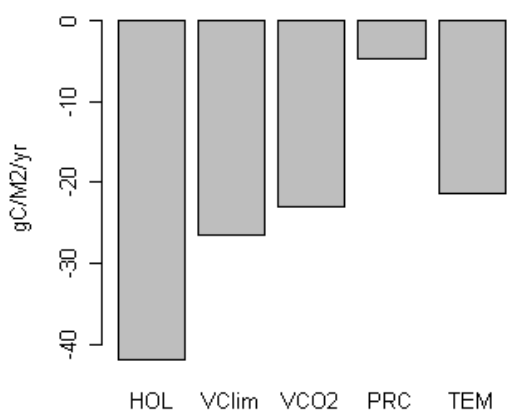

5, 965-1011, 2009

\section{Mid-Holocene} vegetation in Europe

S. Brewer et al.

Title Page

\begin{tabular}{c|c}
\hline Abstract & Introduction \\
\hline Conclusions & References \\
\hline Tables & Figures \\
\hline I4 & $\triangleright$ I \\
\hline 4 & $\triangleright$ \\
\hline Back & Close \\
\hline Full Screen / Esc
\end{tabular}

Fig. 9. NPP changes from different sensitivity experiments performed using the GISSmodelE output. These are: $\mathrm{HOL}=$ change in climate and $\mathrm{CO}_{2}$ concentration; VClim = change in climate; $\mathrm{VCO} 2$ = change in $\mathrm{CO}_{2}$ conc.; $\mathrm{PRC}=$ Holocene precipitation and modern temperature; $\mathrm{TEM}=$ Holocene temperature and modern precipitation. Values are given as regional averages for NW/NE/SW/SE Europe.

Interactive Discussion

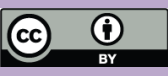


5, 965-1011, 2009

GISSmodelE Wind Anomaly

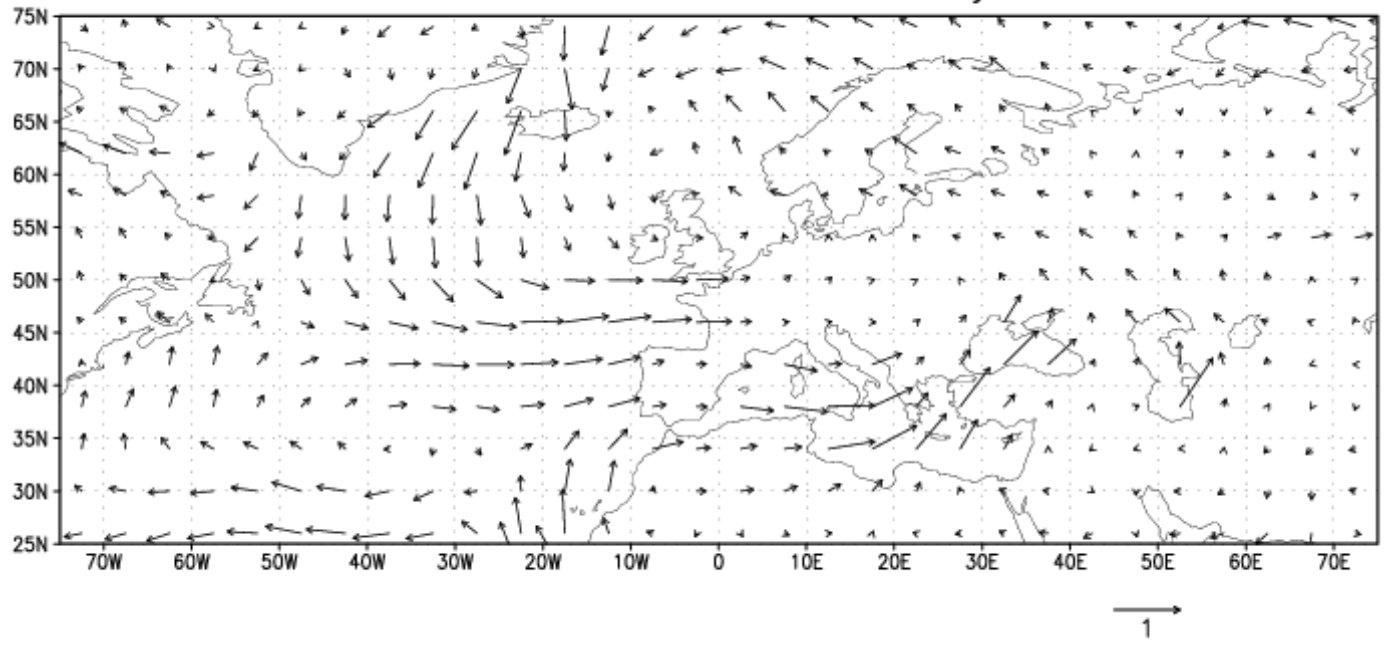

Fig. 10. (a) Simulated changes in wind speed and direction for the Mid-Holocene for GISSmodelE. The scale of wind speed is given below the figure.

\section{Mid-Holocene vegetation in Europe}

S. Brewer et al.

\begin{tabular}{|c|c|}
\hline \multicolumn{2}{|c|}{ Title Page } \\
\hline Abstract & Introduction \\
\hline Conclusions & References \\
\hline Tables & Figures \\
\hline I4 & \\
\hline 4 & $-\mathbf{I}$ \\
\hline Back & Close \\
\hline Full Screen / Esc
\end{tabular}

Printer-friendly Version

Interactive Discussion 
5, 965-1011, 2009

IPSL-CM4-V1-MR Wind Anomaly

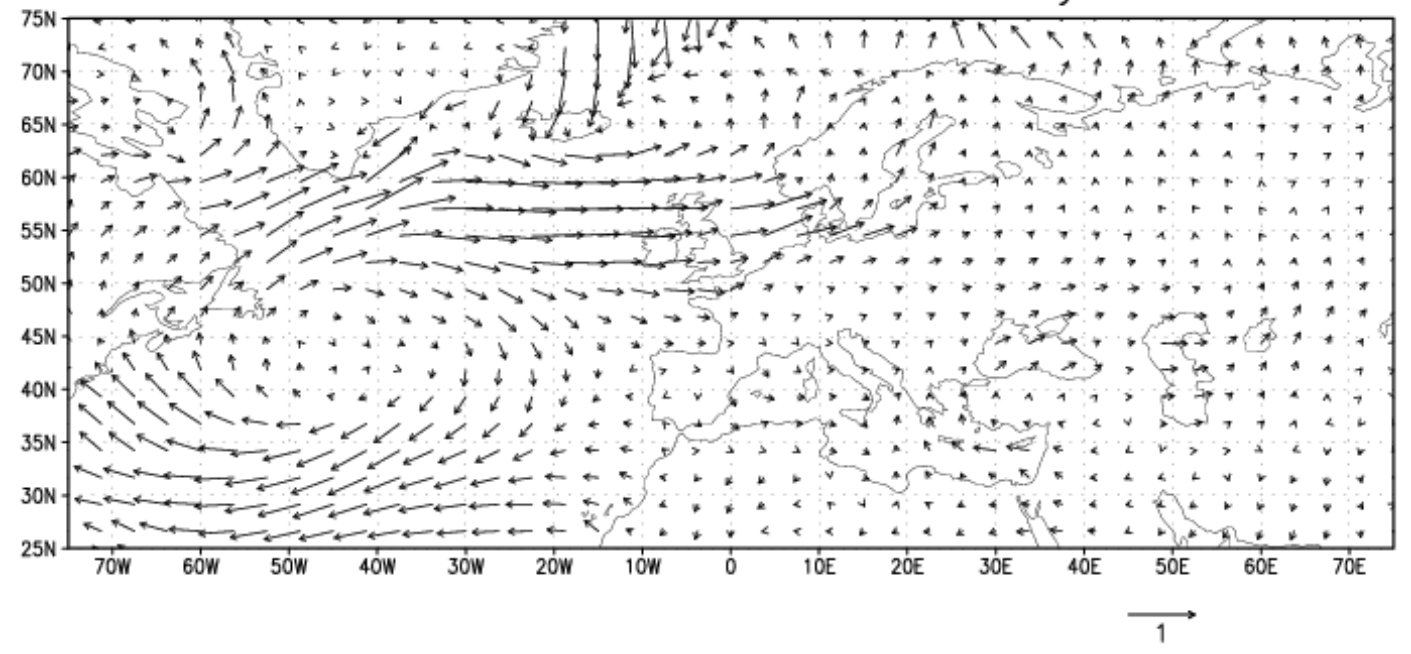

Fig. 10. (b) Simulated changes in wind speed and direction for the Mid-Holocene for IPSLCM4-V1-MR. The scale of wind speed is given below the figure.

\section{Mid-Holocene vegetation in Europe}

S. Brewer et al.

\begin{tabular}{|c|c|}
\hline \multicolumn{2}{|c|}{ Title Page } \\
\hline Abstract & Introduction \\
\hline Conclusions & References \\
\hline Tables & Figures \\
\hline I4 & $-\mathbf{I}$ \\
\hline 4 & $\bullet$ \\
\hline Back & Close \\
\hline Full Screen / Esc
\end{tabular}

Printer-friendly Version

Interactive Discussion 